\title{
Petrography, geochemistry and geochronology of the potassic granitoids of the Rio Itacambiruçu Supersuite: implications for the Meso- to Neoarchean evolution of the Itacambira-Monte Azul block

\author{
Samuel Moreira Bersan ${ }^{1 *}$, André Danderfer Fillho ${ }^{1}$, \\ Francisco Robério de Abreu $^{2}$, Cristiano Lana ${ }^{1}$
}

\begin{abstract}
In the Itacambira-Monte Azul block (BIMA) the Archean rocks are represented by tonalite-trondhjemite-granodiorite (TTGs) of the Porteirinha Complex and by potassic granitoids of the Rio Itacambiruçu Suite that crop out at the Pedra do Urubu (PUp), Rio Gorutuba (RGp), Barrocão (BAp) and Lagoa Nova (LNp) plutons. This work presents new data for the PUp, RGp and BAp. The petrographic and lithochemical analyses allowed the subdivision of the Rio Itacambiruçu Suite in two groups of granitoids: a medium potassium group, represented by the PUp and RGp, and a high potassium group, in which the BAp rocks are inserted. The geochronological data showed different ages for the medium and high potassium groups, with crystallization ages at ca. $2.92 \mathrm{Ga}$ and $2.65 \mathrm{Ga}$, respectively. Despite the differences observed between these two groups, the chemical signatures of these rocks are compatible with the signature of biotite-granites generated by the reworking of ancient continental crust. Thereby, the data obtained in this work, added to some previously published results, allowed to the identification of two Archean crustal stabilization events recorded in BIMA, one of Mesoarchean age and the other of Neoarchean age. In addition, we propose the lithodemic reclassification of the Rio Itacambiruçu Suite to Rio Itacambiruçu Supersuite.
\end{abstract}

KEYWORDS: São-Francisco paleocontinent; Archean; high-K granitoids; basement; Itacambira-Monte Azul block.

\section{INTRODUCTION}

A considerable portion of the present-day continental crust was built early in the evolution of the planet; it is widely accepted that approximately $50 \%$ of the crust was consolidated before $2.5 \mathrm{Ga}$ (Armstrong 1981, Belousova et al. 2010, Dhuime et al. 2011, Guitreau et al. 2012). Important changes in the composition of the crust and crustal-building mechanisms occurred at the end of the Archean, mainly between 3.0 Ga and 2.5 Ga. During this period, the dominantly sodic crust of Paleoarchean tonalite-trondhjemite-granodiorite (TTG) complexes began to exhibit a granitic and predominantly potassic signature (Martin et al. 2005, Moyen et al. 2003, Laurent et al. 2014, Halla et al. 2017). These potassic-rich rocks represent at least $20 \%$ of the total exposed Archean rocks and consist of different types of granitoids (e.g., sanukitoids, biotite and two-mica granites, peralkaline granitoids) that mark the thermal stabilization of the Archean lithosphere (Moyen et al. 2003, Laurent et al. 2014). Although they are more common in the Neoarchean, the occurrences of these potassic granitoids are not restricted to this era, since Mesoarchean potassic granitoids have been described, for

${ }^{1}$ Departamento de Geologia, Universidade Federal de Ouro Preto - Ouro Preto (MG), Brazil. E-mail: samuelbersan@gmail.com, andre@degeo.ufop.br, cristianodeclana@gmail.com

${ }^{2}$ Sustain Geologia - Belo Horizonte (MG), Brazil. E-mail:f_deabreu@yahoo.com

*Corresponding author.

Manuscript ID: 20170131 Received on: 11/01/2017. Accepted on: 01/29/2018. 
example, in the Pilbara (Smithies \& Champion 2000) and Amazonas cratons (Almeida et al. 2010, 2013).

The Brazilian counterpart of the São Francisco-Congo paleocontinent is part of the Atlantic shield, which is exposed in the South American platform and records an evolutionary history ranging from the Paleoarchean to the Paleoproterozoic (Almeida 1977, Alkmim et al. 1993) (Figs. 1A and 1B). Its crustal stabilization occurred at the
A

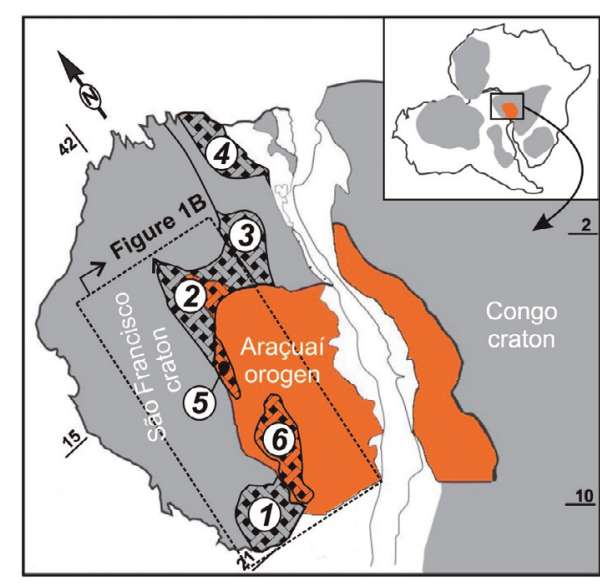

Archean basement domains

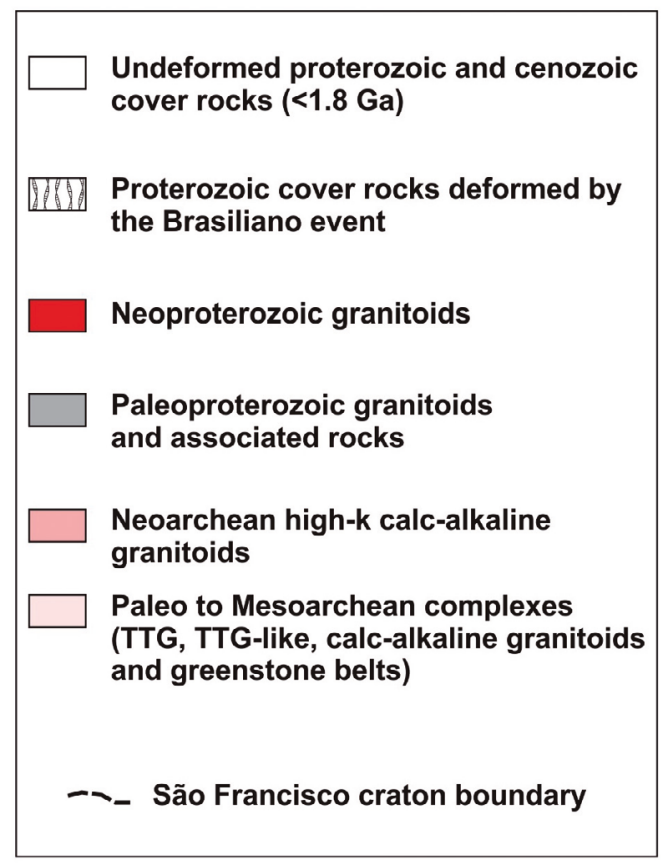

B

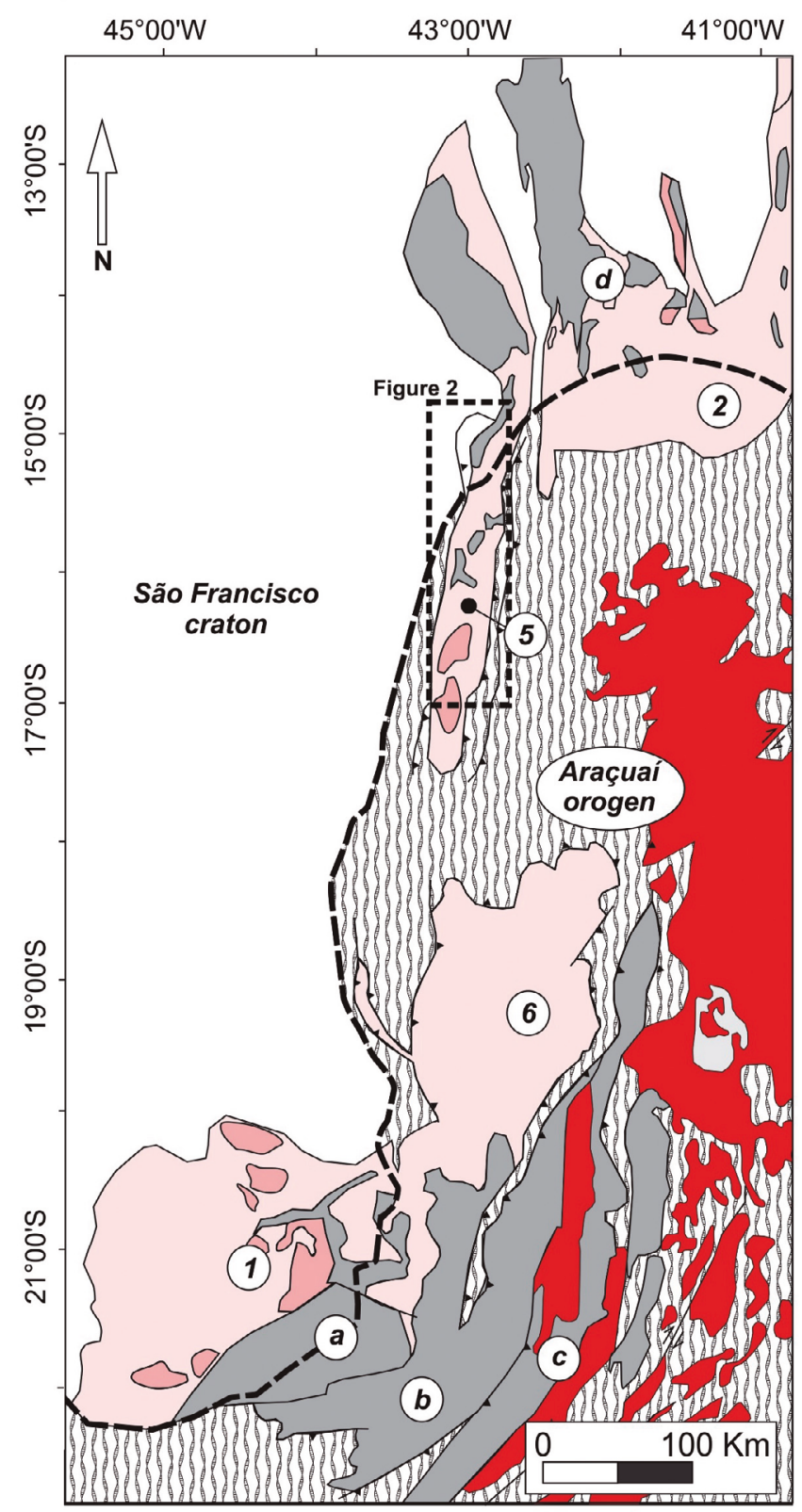

TTG: tonalite-trondhjemite-granodiorite; 1: Archean core of the southern São Francisco Craton; 2: Gavião block; 3: Jequié block; 4: Serrinha block; 5: Itacambira-Monte Azul block (BIMA); 6: Guanhães block and Gouveia anticline; a: Mineiro belt; b: Mantiqueira Complex; c: Juiz de Fora Complex; d: Western Bahia magmatic arc.

Figure 1. (A) Geotectonic contextualization of the São Francisco-Congo cratons in the context of western Gondwana, highlighting the regions where Archean rocks occur (modified from Alkmim et al. 2006). (B) Simplified geological map highlighting the Archean and Paleoproterozoic assemblages that integrate both the basement of the São Francisco craton and the Araçuaí orogen (modified from Silva et al. 2016 and Cruz et al. 2016). 
end of global Paleoproterozoic orogenic events, in which several Archean blocks were amalgamated together during the Siderian-Orosirian periods (Alkmim 2004). During the Neoproterozoic, some orogenic events that culminated in the formation of the Gondwana supercontinent reworked the edges of the São Francisco-Congo paleocontinent. As a result, the crustal segments that were not affected by this deformation became integrated within the substrate of the São Francisco-Congo craton, while the reworked areas integrated the substrate of the Neoproterozoic orogens that developed in the margins of this cratonic domain (Almeida 1977, Alkmim et al. 1993) (Figs. 1B and 1C).

In recent years, several studies have paid special attention to the Archean evolution of the Brazilian counterpart of the Sáo Francisco-Congo craton basement (e.g., Martin et al. 1997, Barbosa \& Sabaté 2004, Lana et al. 2013, Romano et al. 2013, Farina et al. 2015, Zincone et al. 2016, Moreno et al. 2017). However, the Archean basement of the Neoproterozoic orogens bordering the São Francisco craton, especially the Araçuaí orogen (Figs. $1 \mathrm{~B}$ and $1 \mathrm{C}$ ), has not been well studied. In these areas, most investigations are regional in their scope (e.g., Silva et al. 2002, Noce et al. 2007, Silva et al. 2016).

A considerable part of the Archean basement of the Araçuaí orogen is exposed in the Itacambira-Monte Azul block (BIMA) (Guimarães et al. 1993, Crocco-Rodrigues et al. 1993), along the eastern border of the São Francisco craton (Figs. 1 and 2). In this region, the Archean basement is represented by the TTG gneisses of the Porteirinha Complex and by some granitoids that have been grouped in the Rio Itacambiruçu Suite (Grossi-Sad et al. 1997). The Rio Itacambiruçu Suite comprises several plutons that were defined by Grossi-Sad et al. (1997) as: the Pedra do Urubu pluton (PUp), the Rio Gorutuba pluton (RGp), the Barrocão pluton (BAp) and the Lagoa Nova pluton (LNp) (Fig. 2). However, these rocks have not been thoroughly studied yet, and very little data for these rocks have been published (Silva et al. 2016). To characterize the tectonic nature of the magmatism of the Rio Itacambiruçu Suite, this work presents new petrographic and geochemical data for the PUp, RGp and BAp, in addition to a new geochronological analysis of the PUp. The results obtained in this study represent a first step for further investigations of these plutons and provide a better understanding of the Archean evolution of the BIMA.

\section{GEOLOGICAL SETTING}

The Archean and Paleoproterozoic basement rocks of the Sáo Francisco-Congo paleocontinent occur in the São
Francisco craton and the bordering Neoproterozoic orogenic tectonic domains (Figs. $1 \mathrm{~B}$ and $1 \mathrm{C}$ ). In the cratonic domain, the basement rocks crop out in the Archean core of the southern portion of the São Francisco craton, the Gavião, Serrinha and Jequié blocks, the Mineiro and ItabunaSalvador Curaça belts and the Western Bahia magmatic arc (Figs. 1B and 1C) (Cruz Pereira et al. 2016, Teixeira et al. 2017, Barbosa \& Barbosa 2017, Alkmim \& Teixeira 2017). In the northern São Francisco craton, the Gavião, Jequié and Serrinha blocks show distinct Archean evolutionary histories, as the amalgamation of these microcontinents occurred during the course of the Paleoproterozoic (Barbosa \& Sabaté 2004, Teixeira et al. 2017). To the east of the São Francisco craton, in the tectonic domain of the Araçuaí orogen, the basement is generically characterized by granite-gneiss complexes that were partly reworked and dismembered during the Neoproterozoic orogeny, which caused these units to be exposed in the external (Araçuaí fold and thrust belt) and internal (Araçuaí metamorphic nucleus) subdomains of this orogen (Noce et al. 2007). In this orogen, the main exposures of basement rock terrains are located in the eastern edge of the Quadrilátero Ferrifero (QF), in the Mantiqueira and Juiz de Fora complexes, at the southern segment of the orogen, and in the Guanhães, Gouveia and BIMA blocks, in its central-northern segment (Alkmim 2004, Noce et al. 2007) (Figs. $1 \mathrm{~B}$ and $1 \mathrm{C}$ ).

The BIMA is approximately $240 \mathrm{~km}$ long by $30-40 \mathrm{~km}$ wide and borders the eastern portion of the São Francisco craton; it is part of the Espinhaço fold and thrust belt in the outer zone (peri-cratonic region) of the Araçuaí orogen (Fig. 1C) (Crocco-Rodrigues et al. 1993, Alkmim et al. 2006). This Archean/Paleoproterozoic block is bordered by the Paleoproterozoic to Mesoproterozoic metasedimentary rocks of the Espinhaço Supergroup to the east and south, and by the Neoproterozoic metasedimentary rocks of the Macaúbas and Bambuí groups to the west (Drumond et al. 1980, Crocco-Rodrigues et al. 1993, Grossi-Sad et al. 1997) (Fig. 2). To the north, the eastern portion of the Gaviaa block is in contact with the Rio Verde Pequeno shear zone (Bertoldo 1993, Bersan 2015). Due to reworking during the construction of the Araçuaí orogen, the zircons of the granitoids exposed within the BIMA have experienced lead loss (Silva et al. 2016).

The BIMA generally comprises the Archean rocks of the Porteirinha Complex and the Rio Itacambiruçu Suite, a volcano-sedimentary sequence of the Riacho dos Machados Group, and several Paleoproterozoic igneous plutons of an undefined nature that have been mapped as the Paciência and Catolé suites (Guimarães et al. 1993, Grossi-Sad et al. 1997, Knauer et al. 2007, Bersan 2015) (Fig. 2A). The predominantly gneissic-migmatitic rocks of the Porteirinha 
A

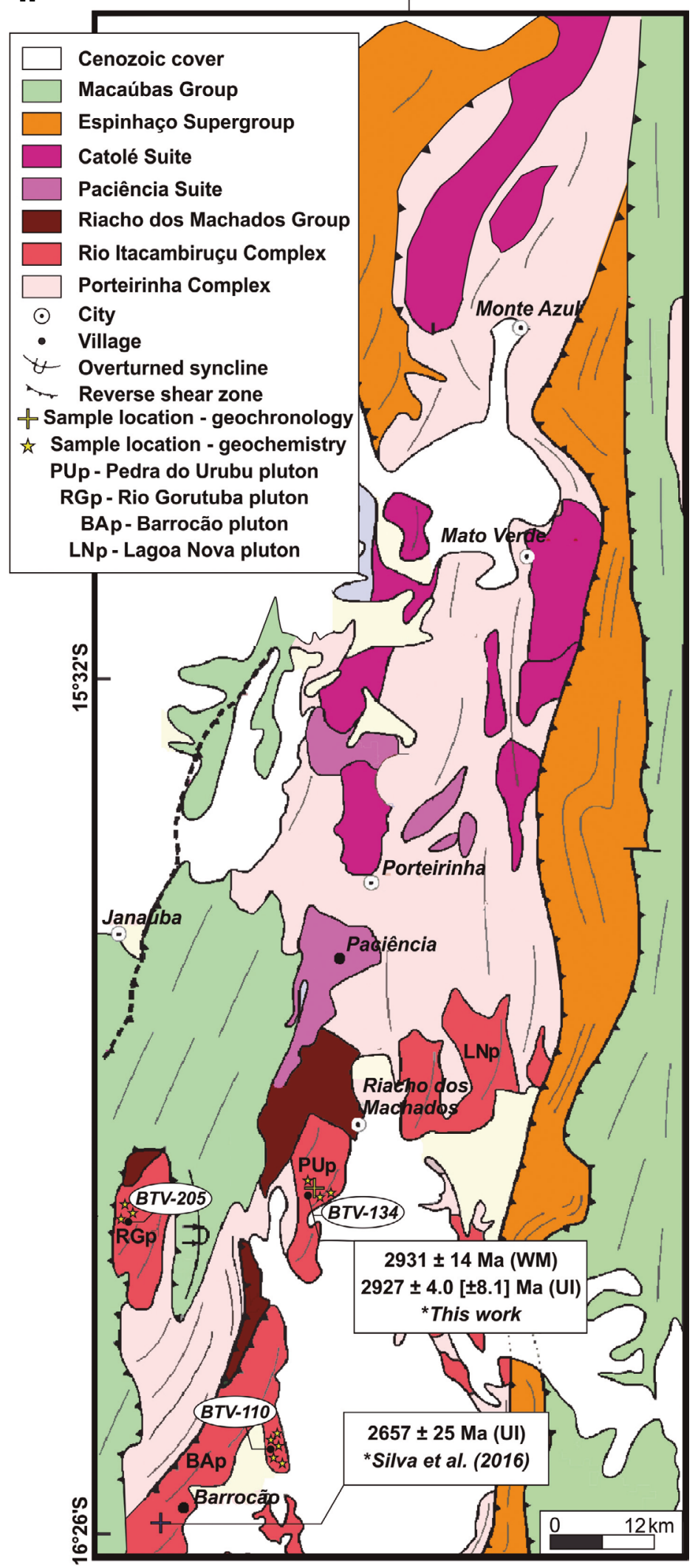

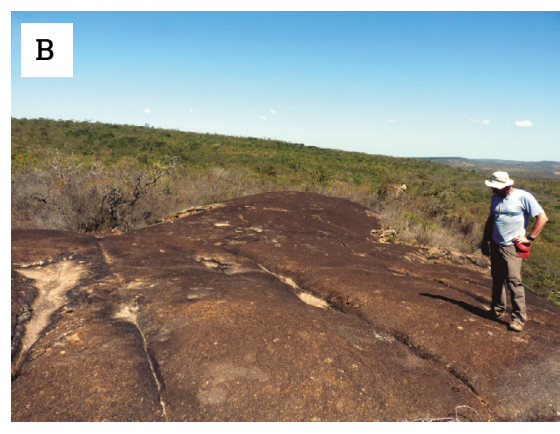
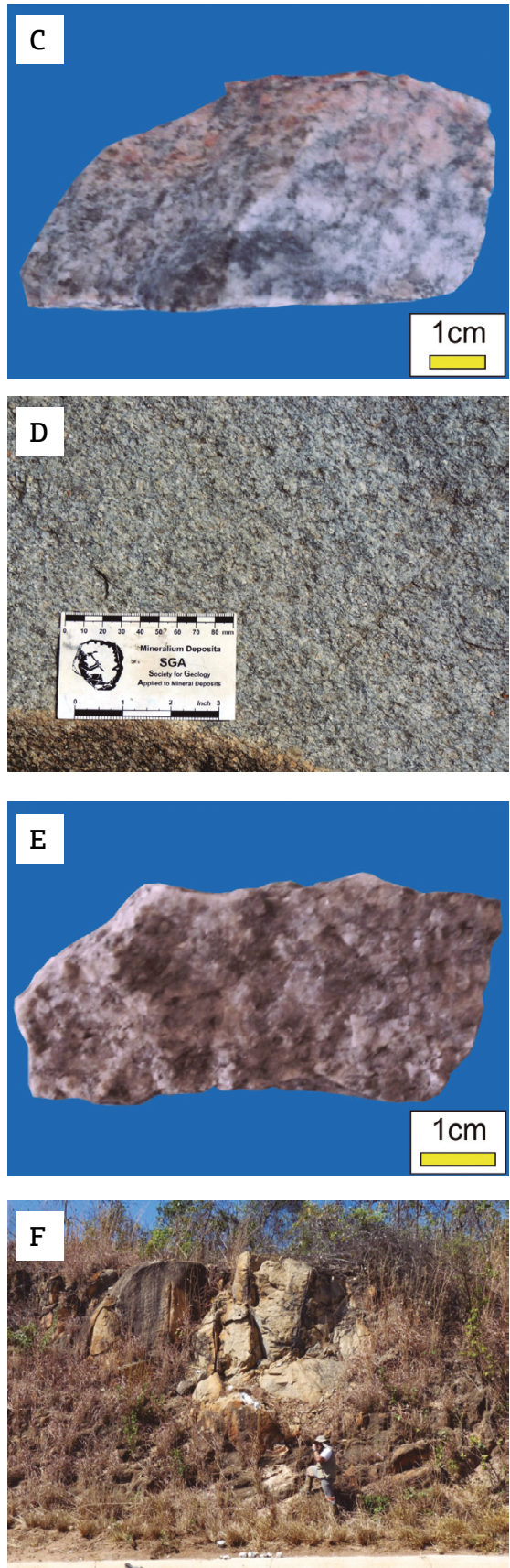

WM: Weighted mean age; UI: Upper intercept age.

Figure 2. (A) Simplified geological map of Itacambira-Monte Azul block (modified from Silva et al. 2016). Main outcrop aspects of the studied plutonites: (B and C) Pedra do Urubu; (D and E) Rio Gorutuba; (F) Barrocão. 
Complex, which have a crystallization age of $3371 \pm 6 \mathrm{Ma}$, are distributed throughout the extent of the BIMA and exhibit a signature that is characteristic of TTG magmas that derivate mainly from the partial melting of a ca. $3.5 \mathrm{Ga}$ primitive oceanic crust, as pointed out by the $\mathrm{Nd}$ isotopic results (Silva et al. 2016). Silva et al. (2016) also reported a first tectonometamorphic regional event in the Porteirinha TTG gneiss, dated at $3145 \pm 24 \mathrm{Ma}$ (M1). So far, this is the oldest directed metamorphic event to have been dated in Brazil. Additionally, the same analysis showed a second, less precise, $698 \pm 85 \mathrm{Ma}$ (M2) metamorphic age, attributed to the Araçuaí main regional metamorphic event.

The main exposures of the Rio Itacambiruçu Suite occur in the central-southern portion of the BIMA and consist of several granitoid plutons, the studies of which are mainly based on petrographic and structural descriptions performed following regional-scale mapping, with few geochemical and geochronological interpretations (Drumond et al. 1980, Grimaráes et al. 1993, Grossi-Sad et al. 1997). These granitoid bodies comprise the PUp, RGp, BAp and LNp plutons (Fig. 2A). According to Grossi-Sad et al. (1997), the Rio Itacambiruçu Suite is composed of equigranular to porphyritic granitoids. The modal compositions of these rocks reflect the predominance of granitic lithologies, as their main mineralogy comprises quartz, feldspars and subordinate biotite with variable proportions of muscovite/sericite. Sometimes, these granitoids may exhibit a prominent foliation defined by the orientation of mafic minerals. In addition, N-S-trending centimetric to decimetric shear zones can also affect these rocks. The contact between the Rio Itacambiruçu Suite and the Porteirinha Complex is rarely observed and has been defined as intrusive by Guimarães et al. (1993) and Grossi-Sad et al. (1997). These authors have also described evidence of localized migmatization processes that are imprinted over the rocks of this suite. Recently, a sample of the BAp syenogranite was analyzed by Silva et al. (2016), for which an upper intercept age of $2657 \pm 25 \mathrm{Ma}$ (U-Pb SHRIMP) was obtained and interpreted as the crystallization age of this rock. The results show chemical and isotopic signatures (negative $\varepsilon \mathrm{Nd}(-2.66)$, depleted-mantle model age - TDM of $3.28 \mathrm{Ga}$ ) suggesting a crustal-like source that may have been generated from the partial melting of the TTGs of the Porteirinha Complex.

The Riacho dos Machados Group, whose age is not established in the literature, corresponds to a meta-volcano-sedimentary sequence that predominantly comprises a diverse series of schists that have been metamorphosed at amphibolite facies (Guimaráes et al. 1993, Fonseca et al. 1996, Grossi-Sad et al. 1997). The lithogeochemical signature of the basal volcanic units in this sequence indicates an association compatible with an island arc environment
(Fonseca 1993, Fonseca et al. 1996). The contact between the Rio dos Machados Group and the granitoids of the Rio Itacambiruçu Suite is tectonic and is marked by reverse shear zones (Fonseca et al. 1996, Grossi-Sad et al. 1997; Fig. 2A).

The Rhyacian to Orosirian Paciência and Catolé suites, respectively (Silva et al. 2016), are interpreted as the youngest granitoids exposed within the BIMA (Grossi-Sad et al. 1997). Generally, the Paciência Suite involves syenitic, monzonitic and granitic rocks of an alkaline nature, while the Catolé Suite comprises calc-alkaline granodiorites and granites that are more evolved and differentiated (Fig. 2A).

\section{ANALYTICAL METHODS}

The field campaign aimed to describe the key outcrops of PUp, RGp and BAp and to collect samples for petrographic, lithochemical and geochronological analyses (Fig. 2). The thin sections used for petrographic characterization were made at the Geology Department of the Universidade Federal de Ouro Preto (DEGEO-UFOP). A total of 12 samples without evidence of weathering were collected for whole-rock major and trace element analyses. One sample was collected from $\mathrm{PUp}$ for $\mathrm{U}-\mathrm{Pb}$ zircon geochronologic analysis.

The initial preparation of whole-rock lithochemical samples was carried out in the sample preparation laboratory (LOPAG) of DEGEO-UFOP. The selected samples were first cleaned to remove any weathering rinds or other contaminants. After this initial process, the samples were crushed and then powdered. Sample powders were analyzed at ACME Analytical Laboratories Ltda./Bureau Veritas Mineral Laboratories. Major and trace element concentrations were determined using Inductively Coupled Plasma Atomic Emission Spectroscopy (ICP-AES) and Inductively Coupled Plasma — Mass Spectrometry (ICP-MS), respectively. The detection limits are $0.01 \%$ for major oxides and $0.1 \mathrm{ppm}$ for most trace elements. For major oxide contents, the samples were digested with nitric acid and then fused using lithium metaborate/tetraborate. The loss on ignition (LOI) was calculated based on the weight difference after the samples were placed in an oven at a temperature of $1,000^{\circ} \mathrm{C}$. Prior to ICP-MS analysis, which was used to measure the concentrations of trace elements, including rare earth elements, the samples were leached in hot Aqua Regia $\left(95^{\circ} \mathrm{C}\right)$. Data were treated using Microsoft Excel spreadsheets and the GCDkit software (version Win 3.00 of 2013; Janousek et al. 2006).

For the U-Pb geochronological analyses, approximately $15 \mathrm{~kg}$ of the PUp sample were subjected to the usual processes of comminution (crushing and grinding) and concentration of heavy minerals at LOPAG-DEGEO-UFOP. Zircon grains 
were handpicked under a binocular microscope, mounted in epoxy disks, and then polished to expose the grain centers. The morphological features and internal structures of zircon grains were analyzed via backscattered electron (BSE) and cathodoluminescence (CL) images obtained at the Universidade de Sáo Paulo (USP) microscopy laboratory using an scanning electron microscope (SEM) (JEOL 6510). U-Pb isotopic compositions were analyzed using a Thermo Scientific Element 2 sector field (SF) ICP-MS equipped with a CETAC LSX-213 G2 + laser ablation system in the laboratory of radiogenic isotopes of DEGEOUFOP. The GJ1 (Jackson et al. 2004) and BB (Santos et al. 2017) standards were used to test the validity and reproducibility of the results obtained (supplementary table 1). Data were reduced using the Glitter Shortcut software (Van Achterbergh et al. 2001), and all ages were calculated and plotted on concordia diagrams using IsoplotEx 4.15 software (Ludwig 2003). The common Pb correction methodology is similar to that described by Farina et al. (2015).

\section{RESULTS}

\section{Petrography}

The PUp (BTV-134) and RGp (BTV-205) rocks are petrographically distinct from the BAp rocks (BTV-110). The PUp (Figs. 2B and 2C) and RGp (Figs. 2D and 2E) rocks dominantly comprise gray/grayish inequigranular granitoids (medium- to coarse-grained) that sometimes exhibit porphyritic texture. These granitoids generally have a massive texture, although foliated and mylonitic rocks have also been described. The studied PUp and RGp samples typically contain quartz (30-40\%), plagioclase (30-35\%), microcline (20-30\%), and biotite (2-15\%), with subordinate quantities of titanite, allanite, epidote, zircon, apatite and opaque minerals, thus encompassing the modal classification of granodiorites (PUp) and monzogranites (RGp). White mica and sericite (formed by the weathering of feldspars or replacing biotite), chlorite (replacing biotite), and calcite (formed by the breakdown of plagioclase) occur as secondary phase minerals, which also include epidotes generated from the saussuritization of plagioclase. A considerable decrease in the modal proportions of biotite, magmatic epidote, allanite, titanite and zircon is observed between the PUp and RGp rocks, with the latter being dominated by leucocratic phases.

The BAp rocks (Fig. 2F) are medium-grained leucogranites that are enriched in K-feldspars and depleted in biotite (almost absent) compared to the PUp and RGp rocks. These rocks are classified as syenogranites, and their modal compositions comprise quartz $(\neg 40 \%)$, microcline $(35-45 \%)$, plagioclase (up to $25 \%$ ) and biotite $(<2 \%)$. Their accessory minerals include zircon, apatite, titanite, epidote and opaques; their secondary minerals phases are similar to those described in PUp and RGp.

In general, the quartz grains are anhedral with undulating extinction in some sections and ranging in size from 2 to $5 \mathrm{~mm}$ (Figs. 3A, 3B and 3C). The plagioclase grains are subidiomorphic with variable sizes. They can exhibit polysynthetic twinning and are mostly sericitized, showing a cloudy alteration appearance in thin sections (Figs. 3A, 3B and 3C). The K-feldspars include microcline crystals with or without perthitic exsolution textures. The microcline grains are anhedral to subhedral and inclusions of quartz, plagioclase, biotite and some accessory phases are a common feature (Fig. 3C). Brown biotite is the only mafic mineral phase described in these rocks; it occurs as anhedral to subhedral flakes dispersed within the interstices of crystals of feldspars and quartz (Figs. 3A, 3D and 3E); in some deformed samples, foliation planes are well defined by this mineral. Subhedral to euhedral magmatic epidote and titanite are associated with biotite and allanite (Figs. 3D, $3 \mathrm{E}$ and $3 \mathrm{~F})$. Sometimes, radial fracture patterns occur in the regions surrounding euhedral allanite crystals bordered by plagioclase.

\section{Whole-rock geochemistry}

As discussed in the petrographic description, the presence of secondary sericite, chlorite and epidote is indicative of some degree of post-magmatic alteration. To verify the degree of weathering that the granitoid rocks experienced, we used the chemical index of alteration (CIA; molar $\mathrm{Al}_{2} \mathrm{O}_{3}$ I $\left.\left(\mathrm{Al}_{2} \mathrm{O}_{3}+\mathrm{CaO}^{*}+\mathrm{Na}_{2} \mathrm{O}+\mathrm{K}_{2} \mathrm{O}\right)\right]$; Nesbitt and Young 1982) and the MFW diagram proposed by Ohta and Arai (2007). The CIA values of the studied samples vary between 50 and 52.5 (Tab. 1) and are within the range of fresh granitoids suggested by Nesbitt and Young (1982). The MFW diagram also indicates that these rocks experienced an insignificant degree of weathering, since the studied samples plot along the fresh igneous rock trend (Fig. 4). These results, together with their low LOI values $(<1 \mathrm{wt} \%)$, suggest that these granitoids did not undergo significant chemical changes and that the geochemical data obtained here can be used for genetic interpretations.

The PUp, RGp and BAp rocks are classified as granites based on the $\mathrm{Na}_{2} \mathrm{O}+\mathrm{K}_{2} \mathrm{O}$ versus $\mathrm{SiO}_{2}$ diagram of Cox et al. (1979) (Fig. 5A). Their An-Ab-Or normative classification (O'Connor 1965) plot in the granite field, highlighting their low calcium content (low An) (Fig. 5B). The analyzed samples have high $\mathrm{SiO}_{2}$ contents, which range from $-73 \mathrm{wt} \%$ for $\mathrm{PUp}$ to $-75 \mathrm{wt} \%$ for RGp and BAp; moderate concentrations of 
$\mathrm{Al}_{2} \mathrm{O}_{3}$ (13.4 to $14.6 \mathrm{wt} \%$ ) and varying proportions of $\mathrm{K}_{2} \mathrm{O}$ (3.32 to 5.8 wt\%), $\mathrm{Na}_{2} \mathrm{O}$ (3.0 to $3.94 \mathrm{wt} \%$ ) and $\mathrm{CaO}(0.8$ to $1.65 \mathrm{wt} \%)$. In general, the BAp rocks are enriched in $\mathrm{K}_{2} \mathrm{O}$, with $\mathrm{K}_{2} \mathrm{O} / \mathrm{Na}_{2} \mathrm{O}$ ratios varying between 1.55 and 1.88 , whereas the PUp and RGp rocks record lower values $\left(0.84<\mathrm{K}_{2} \mathrm{O} /\right.$ $\mathrm{Na}_{2} \mathrm{O}<1.06$ ) (Tab. 1; Figs. 5C and 6A, 6B, 6C, 6D and 6E).

The analyzed samples are weakly peraluminous (A/CNK = 1.02-1.10) and are classified as high-potassium calc-alkaline
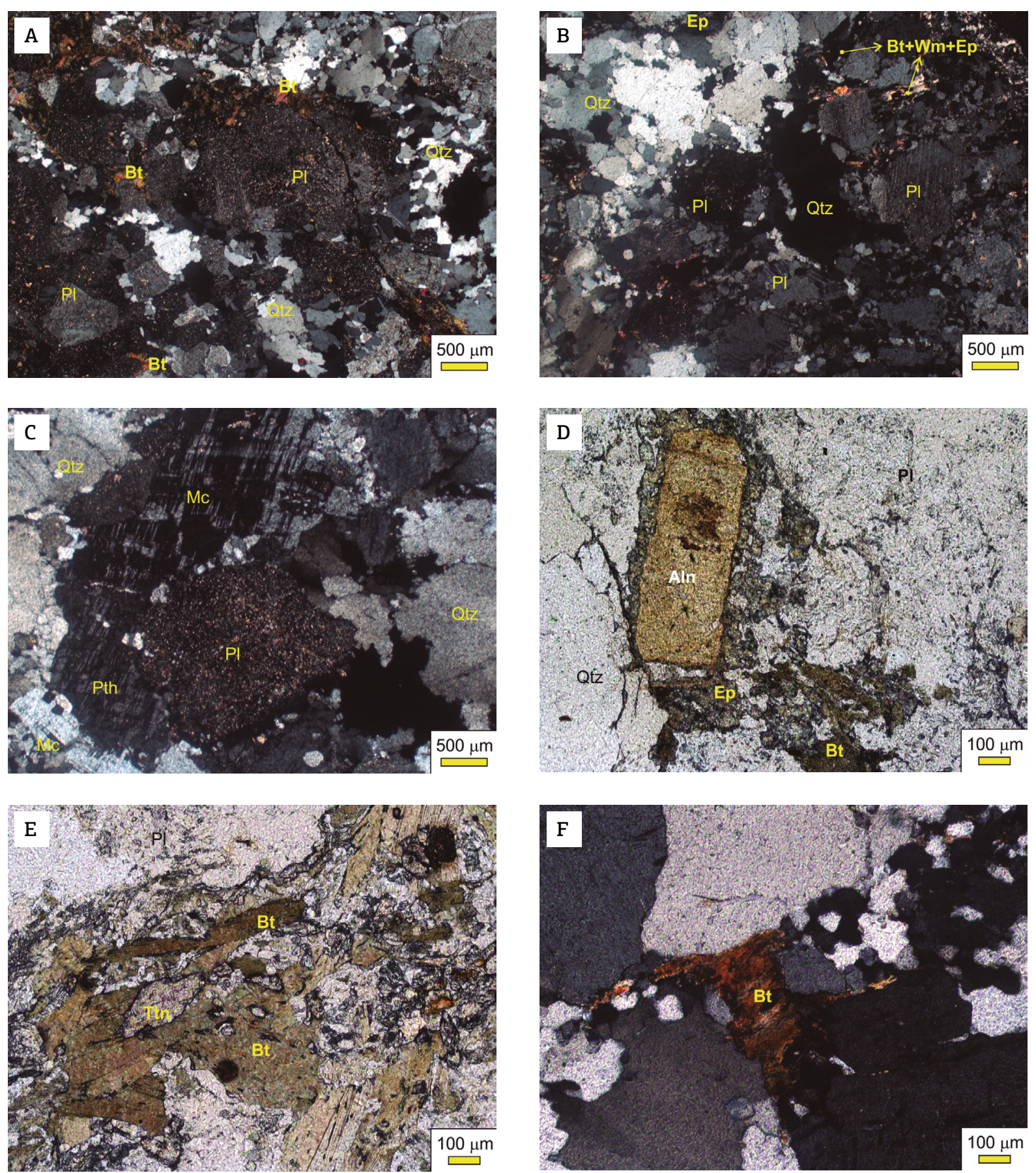

Qtz: quartz; Bt: biotite; Pl: plagioclase; Pth: perthitic feldspar; Mc: microcline alkali-feldspar; Aln: allanite; Ep: epidote; Ttn: titanite; Wm: White mica.

Figure 3. (A, B and C) Photomicrographs showing the main aspects of the Pedra do Urubu (PUp), Rio Gorutuba (RGp) and Barrocão (BAp) plutons, respectively. (D and E) Photomicrographs highlighting the main accessory phases of PUp and RGp. (F) Interstitial biotite flake dispersed within feldspars and quartz observed in a sample of BAp. See text for further explanation. 
Table 1. Major (wt.\%) and trace element concentrations (ppm) of the Pedra do Urubu, Rio Gorutuba and Barrocão granitoids and of Porteirinha Complex gneisses.

\begin{tabular}{|c|c|c|c|c|c|c|c|c|c|c|c|c|c|c|c|c|}
\hline \multirow[b]{2}{*}{ Sample } & \multicolumn{6}{|c|}{ High potassium group } & \multicolumn{6}{|c|}{ Medium potassium group } & \multicolumn{4}{|c|}{ Porteirinha Complex gnaisses } \\
\hline & BTV110A & BTV110B & BTV110C & BTV110D & BTV110E & BTV110F & $\begin{array}{l}\text { BTV- } \\
205 A\end{array}$ & $\begin{array}{l}\text { BTV- } \\
\text { 205B }\end{array}$ & $\begin{array}{l}\text { BTV- } \\
\text { 205C }\end{array}$ & $\begin{array}{l}\text { BTV- } \\
134 A\end{array}$ & $\begin{array}{l}\text { BTV- } \\
\text { 134B }\end{array}$ & $\begin{array}{l}\text { BTV- } \\
134 C\end{array}$ & AS092GQ & AS094GQB & AS095GQ & AS096GQ \\
\hline \multicolumn{17}{|l|}{ (wt.\%) } \\
\hline $\mathrm{SiO}_{2}$ & 75.30 & 72.51 & 74.92 & 74.78 & 75.21 & 74.92 & 75.28 & 75.42 & 74.46 & 73.19 & 73.43 & 73.39 & 70.71 & 69.30 & 74.41 & 69.72 \\
\hline $\mathrm{Al}_{2} \mathrm{O}_{3}$ & 13.51 & 14.67 & 13.56 & 13.64 & 13.60 & 13.54 & 13.40 & 13.54 & 13.62 & 13.63 & 13.54 & 13.36 & 14.59 & 15.89 & 14.38 & 15.34 \\
\hline $\mathrm{Fe}_{2} \mathrm{O}_{3}$ & 0.65 & 1.08 & 0.50 & 0.61 & 0.63 & 0.46 & 1.02 & 0.96 & 1.44 & 2.40 & 2.33 & 2.38 & 3.15 & 2.79 & 1.47 & 3.08 \\
\hline $\mathrm{FeOt}$ & 0.59 & 0.97 & 0.45 & 0.55 & 0.57 & 0.41 & 0.92 & 0.86 & 1.30 & 2.16 & 2.10 & 2.14 & 2.84 & 2.51 & 1.32 & 2.77 \\
\hline $\mathrm{TiO}_{2}$ & 0.09 & 0.11 & 0.07 & 0.09 & 0.09 & 0.07 & 0.10 & 0.09 & 0.15 & 0.28 & 0.27 & 0.27 & 0.41 & 0.31 & 0.14 & 0.40 \\
\hline $\mathrm{MnO}$ & $<0.01$ & 0.01 & $<0.01$ & 0.01 & $<0.01$ & $<0.01$ & 0.03 & 0.03 & 0.04 & 0.04 & 0.04 & 0.04 & 0.05 & 0.04 & 0.02 & 0.04 \\
\hline $\mathrm{MgO}$ & 0.16 & 0.25 & 0.12 & 0.13 & 0.15 & 0.11 & 0.28 & 0.26 & 0.41 & 0.46 & 0.42 & 0.41 & 0.96 & 1.03 & 0.36 & 0.77 \\
\hline $\mathrm{CaO}$ & 0.89 & 1.29 & 0.93 & 0.94 & 0.88 & 0.97 & 1.02 & 0.97 & 1.19 & 1.58 & 1.55 & 1.65 & 2.76 & 3.37 & 2.27 & 2.83 \\
\hline $\mathrm{Na}_{2} \mathrm{O}$ & 3.06 & 3.58 & 3.18 & 3.12 & 3.07 & 3.21 & 3.75 & 3.83 & 3.70 & 3.72 & 3.94 & 3.68 & 4.00 & 4.34 & 4.66 & 4.76 \\
\hline $\mathrm{K}_{2} \mathrm{O}$ & 5.76 & 5.56 & 5.70 & 5.79 & 5.68 & 5.66 & 3.93 & 4.07 & 3.85 & 3.57 & 3.32 & 3.67 & 2.34 & 1.86 & 1.45 & 1.65 \\
\hline $\mathrm{Cr}_{2} \mathrm{O}_{3}$ & $<0.002$ & $<0.002$ & $<0.002$ & $<0.002$ & $<0.002$ & $<0.002$ & n.a & n.a & n.a & n.a & n.a & n.a & n.a & n.a & n.a & n.a \\
\hline $\mathrm{Ni}$ & $<20$ & $<20$ & $<20$ & $<20$ & $<20$ & $<20$ & n.a & n.a & n.a & n.a & n.a & n.a & n.a & n.a & n.a & n.a \\
\hline $\mathrm{P} 205$ & 0.01 & 0.02 & 0.02 & 0.01 & 0.02 & 0.02 & 0.03 & 0.02 & 0.04 & 0.06 & 0.06 & 0.06 & 0.12 & 0.09 & 0.02 & 0.12 \\
\hline LOI & 0.40 & 0.70 & 0.80 & 0.70 & 0.50 & 0.90 & 1.00 & 0.70 & 0.90 & 0.90 & 0.90 & 0.90 & 0.71 & 0.77 & 0.58 & 0.86 \\
\hline Sum & 99.84 & 99.82 & 99.83 & 99.84 & 99.83 & 99.84 & 99.93 & 99.92 & 99.92 & 99.92 & 99.91 & 99.91 & 99.79 & 99.79 & 99.76 & 99.57 \\
\hline \multicolumn{17}{|l|}{ (ppm) } \\
\hline $\mathrm{Ba}$ & 412.00 & 546.00 & 393.00 & 395.00 & 400.00 & 384.00 & 452.00 & 462.00 & 640.00 & 534.00 & 473.00 & 542.00 & - & - & - & - \\
\hline $\mathrm{Be}$ & 2.00 & 2.00 & $<1$ & $<1$ & 1.00 & $<1$ & 1.00 & 3.00 & 1.00 & 3.00 & 1.00 & 2.00 & - & - & - & - \\
\hline Co & 64.60 & 59.10 & 71.00 & 65.40 & 82.50 & 74.40 & 54.00 & 52.50 & 51.60 & 63.40 & 65.40 & 67.40 & - & - & - & - \\
\hline Cs & 1.70 & 2.20 & 1.40 & 1.50 & 1.70 & 1.40 & 2.10 & 2.00 & 3.30 & 3.90 & 2.80 & 2.70 & - & - & - & - \\
\hline $\mathrm{Ga}$ & 14.70 & 16.60 & 13.70 & 14.60 & 14.00 & 14.30 & 15.10 & 15.10 & 15.20 & 18.10 & 17.30 & 15.80 & - & - & - & - \\
\hline $\mathrm{Hf}$ & 3.20 & 4.00 & 3.20 & 2.90 & 3.00 & 3.20 & 2.60 & 2.40 & 4.70 & 5.40 & 5.30 & 4.90 & - & - & - & - \\
\hline $\mathrm{Nb}$ & 3.60 & 5.40 & 2.70 & 3.20 & 3.70 & 2.50 & 5.50 & 5.30 & 8.60 & 11.00 & 10.80 & 10.10 & - & - & - & - \\
\hline $\mathrm{Rb}$ & 154.60 & 161.20 & 154.30 & 154.30 & 152.30 & 153.70 & 146.50 & 152.70 & 132.40 & 152.90 & 144.90 & 139.30 & - & - & - & - \\
\hline Sn & $<1$ & 2.00 & $<1$ & 1.00 & $<1$ & $<1$ & 1.00 & 1.00 & 2.00 & 3.00 & 3.00 & 3.00 & - & - & - & - \\
\hline $\mathrm{Sr}$ & 101.10 & 105.00 & 96.80 & 98.40 & 99.10 & 100.20 & 129.30 & 123.20 & 155.70 & 106.50 & 104.00 & 107.90 & - & - & - & - \\
\hline $\mathrm{Ta}$ & 0.70 & 0.80 & 0.90 & 0.90 & 0.90 & 0.80 & 1.40 & 1.30 & 1.30 & 2.40 & 2.00 & 2.00 & - & - & - & - \\
\hline Th & 22.00 & 36.50 & 21.20 & 20.20 & 21.10 & 20.80 & 16.70 & 15.60 & 23.40 & 24.00 & 27.60 & 22.20 & - & - & - & - \\
\hline $\mathrm{U}$ & 23.70 & 5.70 & 31.30 & 26.10 & 21.70 & 32.10 & 7.80 & 7.90 & 8.80 & 8.10 & 8.60 & 5.00 & - & - & - & - \\
\hline $\mathrm{V}$ & $<8$ & $<8$ & $<8$ & $<8$ & $<8$ & $<8$ & 8.00 & $<8$ & 10.00 & 20.00 & 21.00 & 20.00 & - & - & - & - \\
\hline W & 532.80 & 486.10 & 619.10 & 567.90 & 676.90 & 578.30 & 587.40 & 599.00 & 551.80 & 570.60 & 617.50 & 617.00 & - & - & - & - \\
\hline $\mathrm{Zr}$ & 83.40 & 128.20 & 84.40 & 79.00 & 79.20 & 86.20 & 73.50 & 72.80 & 145.70 & 187.30 & 175.90 & 169.40 & - & - & - & - \\
\hline $\mathrm{Y}$ & 14.70 & 8.50 & 12.10 & 13.50 & 14.50 & 11.60 & 8.70 & 13.30 & 21.60 & 23.90 & 33.20 & 25.40 & - & - & - & - \\
\hline $\mathrm{La}$ & 26.80 & 47.90 & 22.50 & 22.80 & 26.80 & 22.90 & 14.50 & 26.20 & 59.30 & 20.40 & 41.50 & 34.00 & - & - & - & - \\
\hline $\mathrm{Ce}$ & 44.60 & 90.70 & 42.40 & 39.80 & 44.80 & 42.70 & 25.90 & 33.20 & 86.10 & 64.20 & 82.10 & 73.90 & - & - & - & - \\
\hline $\operatorname{Pr}$ & 4.71 & 8.97 & 4.21 & 4.07 & 4.62 & 4.35 & 2.70 & 4.22 & 9.89 & 4.38 & 8.25 & 7.04 & - & - & - & - \\
\hline $\mathrm{Nd}$ & 15.80 & 29.70 & 15.00 & 13.80 & 15.30 & 14.80 & 9.80 & 14.40 & 33.70 & 15.70 & 28.10 & 23.80 & - & - & - & - \\
\hline $\mathrm{Sm}$ & 3.15 & 5.37 & 2.94 & 2.68 & 3.13 & 2.91 & 1.95 & 2.83 & 5.42 & 3.77 & 5.37 & 4.76 & - & - & - & - \\
\hline
\end{tabular}


Table 1. Continuation.

\begin{tabular}{|c|c|c|c|c|c|c|c|c|c|c|c|c|c|c|c|c|}
\hline \multirow[b]{2}{*}{ Sample } & \multicolumn{6}{|c|}{ High potassium group } & \multicolumn{6}{|c|}{ Medium potassium group } & \multicolumn{4}{|c|}{ Porteirinha Complex gnaisses } \\
\hline & BTV110A & BTV110B & BTV110C & BTV110D & BTV110E & BTV110F & $\begin{array}{l}\text { BTV- } \\
\text { 205A }\end{array}$ & $\begin{array}{l}\text { BTV- } \\
\text { 205B }\end{array}$ & $\begin{array}{l}\text { BTV- } \\
205 C\end{array}$ & $\begin{array}{l}\text { BTV- } \\
134 A\end{array}$ & $\begin{array}{l}\text { BTV- } \\
134 B\end{array}$ & $\begin{array}{l}\text { BTV- } \\
134 C\end{array}$ & AS092GQ & AS094GQB & AS095GQ & AS096GQ \\
\hline $\mathrm{Eu}$ & 0.61 & 0.73 & 0.61 & 0.59 & 0.60 & 0.60 & 0.46 & 0.55 & 0.72 & 0.68 & 0.86 & 0.76 & - & - & - & - \\
\hline $\mathrm{Gd}$ & 2.88 & 3.84 & 2.72 & 2.47 & 2.92 & 2.65 & 1.94 & 2.55 & 4.64 & 4.03 & 5.35 & 4.38 & - & - & - & - \\
\hline $\mathrm{Tb}$ & 0.43 & 0.48 & 0.40 & 0.39 & 0.43 & 0.41 & 0.28 & 0.37 & 0.60 & 0.66 & 0.83 & 0.72 & - & - & - & - \\
\hline Dy & 2.30 & 2.12 & 2.20 & 2.19 & 2.41 & 2.25 & 1.72 & 1.99 & 3.02 & 4.05 & 5.12 & 4.40 & - & - & - & - \\
\hline Ho & 0.39 & 0.30 & 0.38 & 0.40 & 0.43 & 0.39 & 0.29 & 0.39 & 0.61 & 0.80 & 1.03 & 0.87 & - & - & - & - \\
\hline $\mathrm{Er}$ & 1.04 & 0.70 & 0.99 & 1.08 & 1.02 & 0.98 & 0.73 & 1.04 & 1.50 & 2.53 & 3.15 & 2.60 & - & - & - & - \\
\hline $\mathrm{Tm}$ & 0.14 & 0.11 & 0.14 & 0.14 & 0.14 & 0.14 & 0.12 & 0.16 & 0.21 & 0.39 & 0.47 & 0.39 & - & - & - & - \\
\hline $\mathrm{Yb}$ & 0.83 & 0.60 & 0.85 & 0.80 & 0.83 & 0.86 & 0.91 & 0.95 & 1.39 & 2.66 & 3.14 & 2.65 & - & - & - & - \\
\hline $\mathrm{Lu}$ & 0.12 & 0.09 & 0.12 & 0.11 & 0.12 & 0.12 & 0.12 & 0.16 & 0.21 & 0.39 & 0.45 & 0.42 & - & - & - & - \\
\hline $\mathrm{Sr} / \mathrm{Y}$ & 6.88 & 12.35 & 8.00 & 7.29 & 6.83 & 8.64 & 14.86 & 9.26 & 7.21 & 4.46 & 3.13 & 4.25 & - & - & - & - \\
\hline HREE & 8.13 & 8.24 & 7.80 & 7.58 & 8.30 & 7.80 & 6.11 & 7.61 & 12.18 & 15.51 & 19.54 & 16.43 & - & - & - & - \\
\hline $\mathrm{Eu} / \mathrm{Eu}^{*}$ & 0.62 & 0.49 & 0.66 & 0.70 & 0.61 & 0.66 & 0.72 & 0.63 & 0.44 & 0.53 & 0.49 & 0.51 & - & - & - & - \\
\hline $\mathrm{LaN} / \mathrm{YbN}$ & 21.77 & 53.82 & 17.85 & 19.21 & 21.77 & 17.95 & 10.74 & 18.59 & 28.76 & 5.17 & 8.91 & 8.65 & - & - & - & - \\
\hline $\mathrm{K}_{2} \mathrm{O} / \mathrm{Na}_{2} \mathrm{O}$ & 1.88 & 1.55 & 1.79 & 1.86 & 1.85 & 1.76 & 1.05 & 1.06 & 1.04 & 0.96 & 0.84 & 1.00 & 0.58 & 0.43 & 0.31 & 0.35 \\
\hline $\mathrm{A} / \mathrm{CNK}$ & 1.05 & 1.03 & 1.04 & 1.04 & 1.06 & 1.03 & 1.09 & 1.09 & 1.10 & 1.06 & 1.05 & 1.03 & 1.03 & 1.04 & 1.08 & 1.04 \\
\hline CIA & 51.18 & 50.72 & 50.88 & 50.99 & 51.52 & 50.69 & 52.19 & 52.06 & 52.31 & 51.46 & 51.22 & 50.63 & 50.82 & 50.98 & 51.83 & 50.97 \\
\hline $\mathrm{Mg} \#$ & 32.77 & 31.44 & 32.22 & 29.68 & 32.05 & 32.14 & 35.22 & 34.91 & 36.06 & 27.52 & 26.31 & 25.44 & 37.64 & 42.24 & 32.66 & 33.12 \\
\hline $\mathrm{M}(\mathrm{TZr})$ & 1.35 & 1.43 & 1.37 & 1.36 & 1.33 & 1.38 & 1.29 & 1.30 & 1.29 & 1.36 & 1.37 & 1.40 & - & - & - & - \\
\hline \multicolumn{17}{|l|}{$\left({ }^{\circ} \mathrm{C}\right)$} \\
\hline $\mathrm{TZr}(\mathrm{W} \& \mathrm{H})$ & 736 & 765 & 735 & 730 & 733 & 736 & 730 & 728 & 785 & 803 & 796 & 791 & - & - & - & - \\
\hline $\operatorname{TZr}(\mathrm{B})$ & 683 & 714 & 682 & 676 & 680 & 683 & 678 & 676 & 742 & 760 & 753 & 745 & - & - & - & - \\
\hline TAp & 732 & 767 & 787 & 732 & 773 & 792 & 786 & 760 & 798 & 845 & 855 & 871 & - & - & - & - \\
\hline
\end{tabular}

LOI: loss on ignition; HREE: heavy rare earth elements.

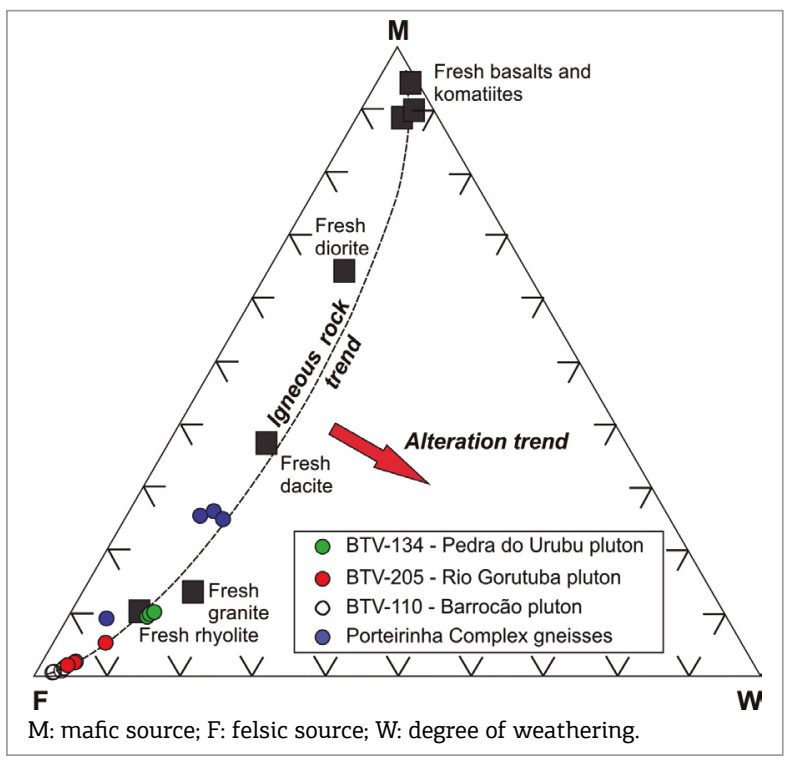

Figure 4. MFW ternary diagram of Ohta and Arai (2007) with the studied granitoids plotting along the fresh igneous rocks trend. For the $\mathrm{M}, \mathrm{F}$ and $\mathrm{W}$ formulas, see Ohta and Arai (2007). series rocks $\left(\mathrm{K}_{2} \mathrm{O}\right.$ versus $\mathrm{SiO}_{2}$ diagram of Gill 1981) (Figs. 5C and 5D). However, on the $\mathrm{SiO}_{2}$ versus $\mathrm{K}_{2} \mathrm{O}+\mathrm{Na}_{2} \mathrm{O}-\mathrm{CaO}$ diagram of Frost et al. (2001), the BAp granitoids are classified as alkali-calcic series rocks, while the PUp and RGp rocks plot in the field of calc-alkaline series rocks (Fig. 5E). These three plutons contain low contents of ferromagnesian oxides, with their $\mathrm{FeO}_{\mathrm{t}}+\mathrm{MgO}$ values ranging from 0.57 to 2.6 wt.\% (Fig. 6). Nevertheless, the PUp and RGp rocks are slightly enriched compared to the BAp rocks. Their $\mathrm{Mg \#}$ values are relatively low (0.25-0.36; Tab. 1); on the $\left(\mathrm{FeO}_{\mathrm{t}}\right.$ / $\left(\mathrm{FeO}_{\mathrm{t}}+\mathrm{MgO}\right)$ versus $\mathrm{SiO}_{2}$ diagram of Frost et al. (2001), the RGp and BAp samples plot in the magnesian field, whereas the PUp samples fall in the magnesian to ferroan transition field (Fig. 5F). The negative correlation between $\mathrm{P}_{2} \mathrm{O}_{5}$ (not show) and $\mathrm{Zr}$ with silica indicates fractionation of apatite and zircon.

In terms of the trace elements, they show moderate values of $\mathrm{Ba}$ (393 to $640 \mathrm{ppm}$ ), Rb (132 to $161 \mathrm{ppm}$ ) and $\mathrm{Sr}(-97$ to $155 \mathrm{ppm})$, which are reflected in their low $\mathrm{Ba} / \mathrm{Rb}$ ratios. Their low contents of transition elements 


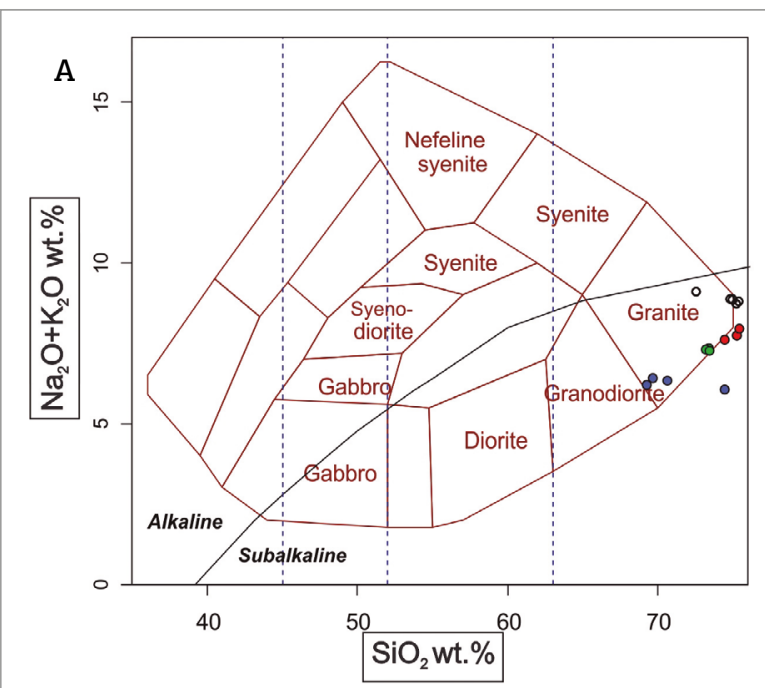

B

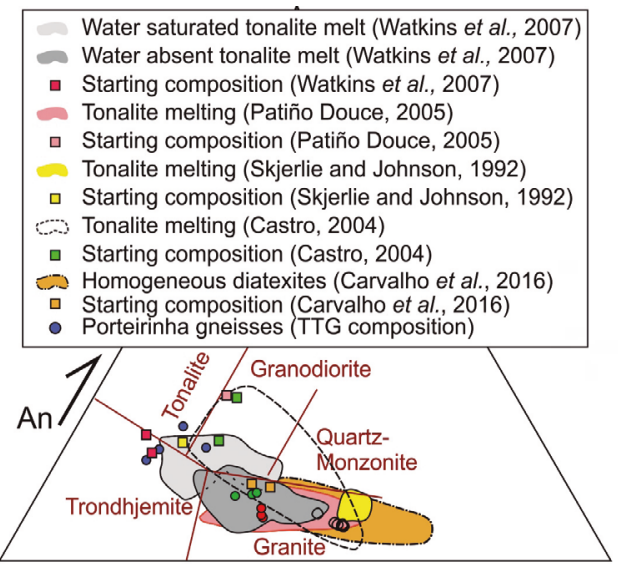

$\mathrm{Ab}$ Or
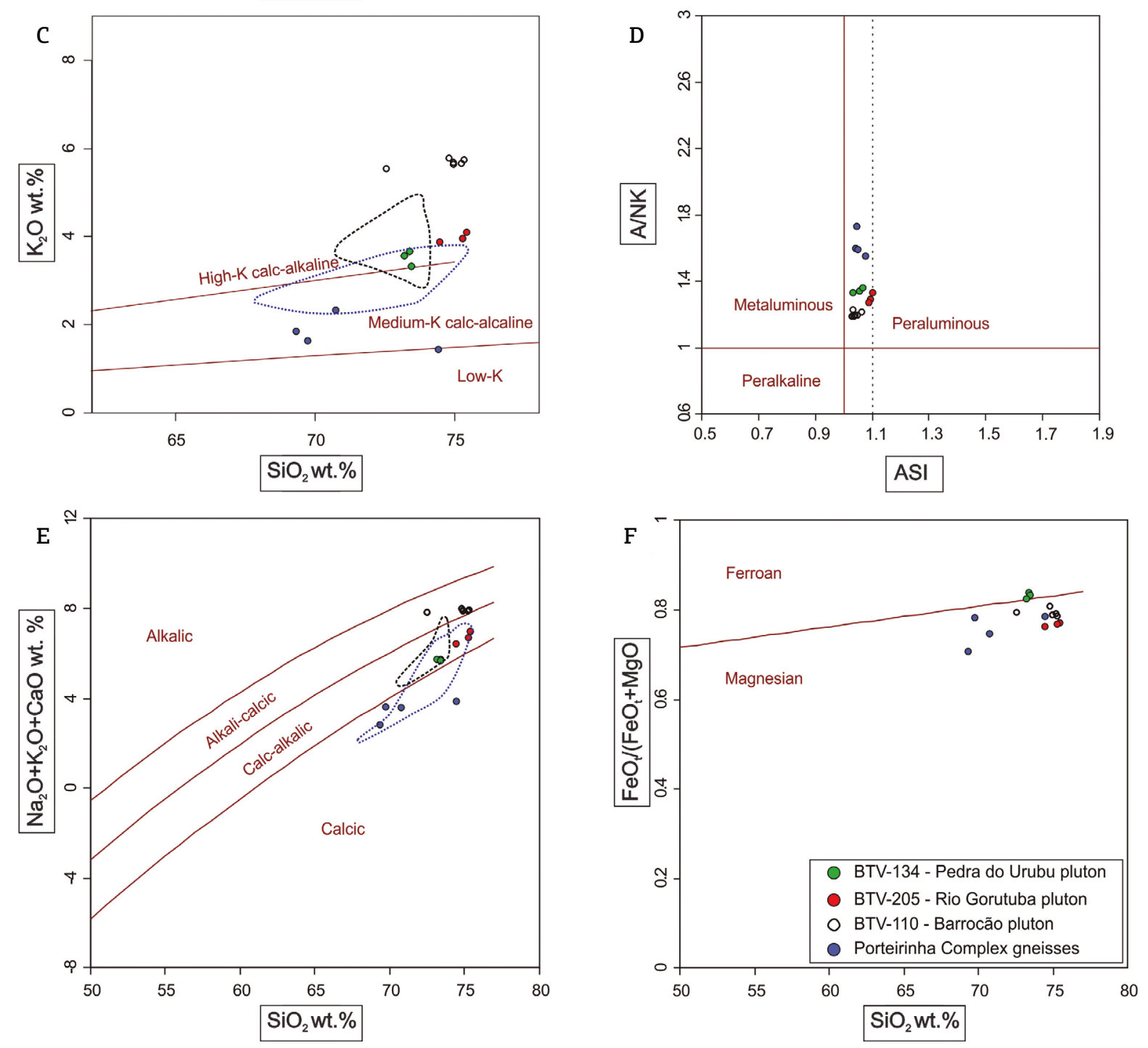

Figure 5. Geochemical classification diagrams for the granitoids of the Pedra do Urubu (PUp), Rio Gorutuba (RGp) and Barrocão (BAp) plutons (references in the text). The black dashed line indicates the average composition of the kfs-bearing granitoids from Farina et al. (2015). The blue dashed line indicates the average composition of the transitional TTGs from Farina et al. (2015). 

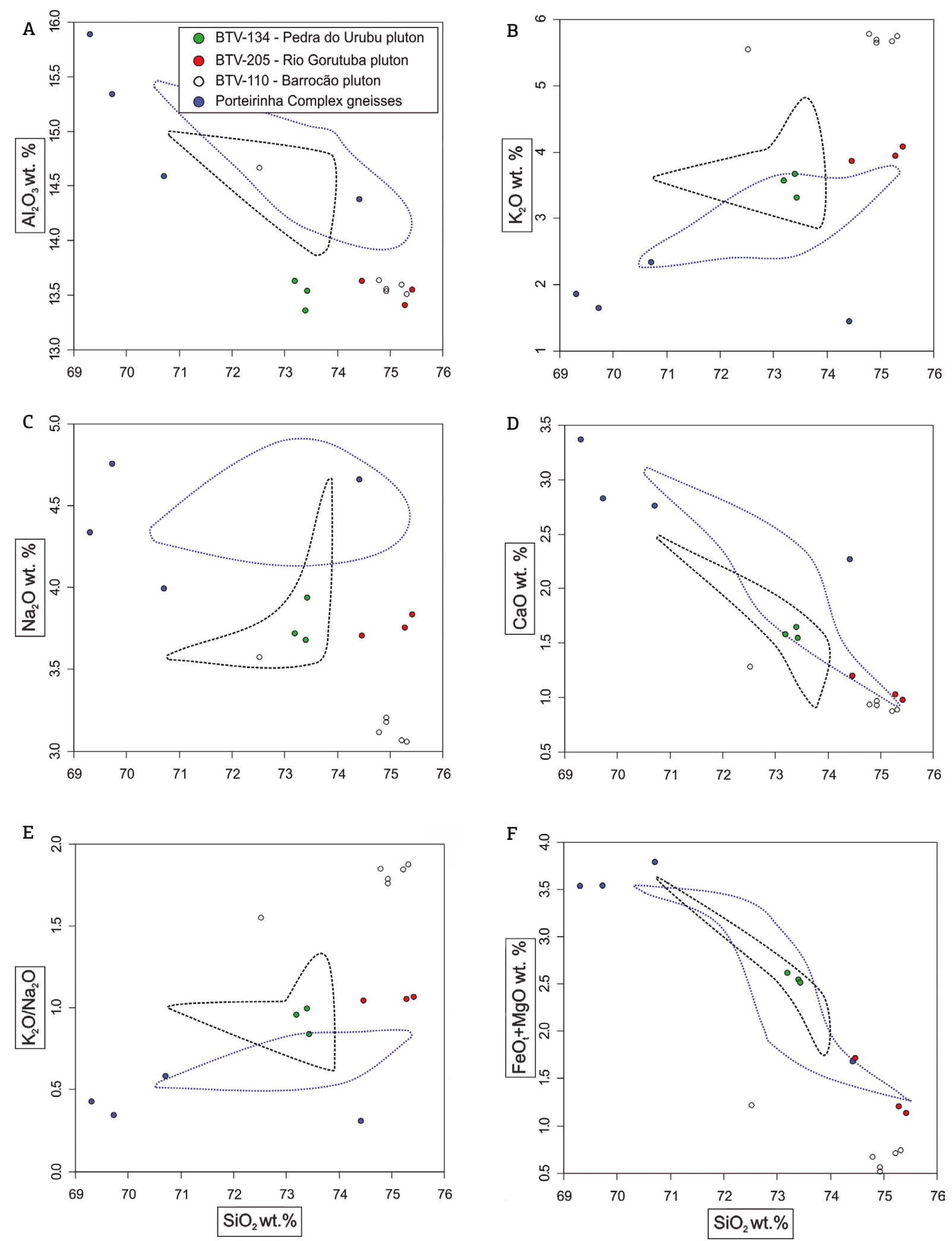

Figure 6. Major oxides Harker diagram of the Pedra do Urubu (PUp), Rio Gorutuba (RGp) and Barrocão (BAp) granitoids. For comparison purposes, the results obtained for four TTG signature gneisses from the Porteirinha Complex are plotted. The black dashed line indicates the average composition of the kfs-bearing granitoids from Farina et al. (2015). The blue dashed line indicates the average composition of the transitional TTGs from Farina et al. (2015). 
such as $\mathrm{Zr}$ (<187 ppm), $\mathrm{V}$ (<21 ppm), $\mathrm{Ni}$ and $\mathrm{Cr}$ (concentrations below the detection limit) were also noticed (Fig. 7 and Tab. 1). On the trace element Harker diagrams, the PUp and RGp granitoids generally have higher concentrations of $\mathrm{Ba}$ and $\mathrm{Sr}$, whereas the $\mathrm{BAp}$ rocks tend to have higher concentrations of $\mathrm{Rb}$ (Figs. 7A, 7B, 7C). In terms of high field strength elements, such as $\mathrm{Zr}$ and $\mathrm{Y}, \mathrm{PUp}$ records concentrations that are up to twice as high as those of the other samples (Figs. 7D and 7E). Therefore, the Sr/Y ratios of the PUp samples ( $\sim 3$ to 4 ) are lower than those of the RGp ( -7 to 14) and BAp ( $\neg 7$ to 12) samples (Fig. 7F).

The chondrite-normalized rare earth element (REE) spider plots (Boynton 1984) show fractional patterns for the three plutons, with a slight enrichment in light rare earth elements (LREE) relative to heavy rare earth elements (HREE). However, the PUp samples are enriched in REE, especially in HREE (Fig. 8A). Thus, the $\mathrm{La}_{\mathrm{N}} / \mathrm{Yb}_{\mathrm{N}}$ ratios of BAp (17.85 to 53.82) and RGp (10.74 to 28.76) are higher than those of $\mathrm{PUp}$ (with ratios ranging from 5.17 to 8.91 ; Tab. 1). Negative Eu anomalies are a common feature, with $\mathrm{Eu} / \mathrm{Eu}^{*}$ ratios ranging from 0.49 to 0.72 ; however, these ratios are relatively lower in the PUp rocks (Fig. 8A and Tab. 1).

The primitive mantle-normalized $(\mathrm{McD}$ Donough \& Sun 1995) spider diagrams (Fig. 8B) exhibit the enrichment of large ion lithophile elements (LILE) and the depletion of some high field strength elements (HFSE) in all granitoid rocks. Negative anomalies of $\mathrm{Ba}, \mathrm{Sr}, \mathrm{Nb}, \mathrm{P}$ and $\mathrm{Ti}$ are a common feature. The negative anomalies of $\mathrm{Ba}$ and $\mathrm{Sr}$, with negative Eu anomalies, would suggest feldspar fractionation. $\mathrm{P}$ and $\mathrm{Ti}$ anomalies may also be indicative of apatite and $\mathrm{Fe}-\mathrm{Ti}$ oxides fractionation, which are also supported by the negative correlation between $\mathrm{P}_{2} \mathrm{O}_{5}$ and $\mathrm{TiO}_{2}$ with silica.

\section{Zircon $\mathrm{U}-\mathrm{Pb}$ geochronology}

Zircon grains collected from a granodiorite of the PUp (sample no. BTV-134) were analyzed using LA-ICP-MS to examine their magmatic ages. A total of 25 analyses were performed, 7 of which showed concordance between 95 and $100 \%$ (Tab. 2). The CL images and analytical spots with the results of U-Pb dating are presented in Figure 9. The zircon grains are euhedral, brownish to translucent, and show oscillatory zoning and aspect ratios ranging from $1 / 2$ to $1 / 3$, thus suggesting that they experienced magmatic crystallization. In addition, the high $\mathrm{Th} / \mathrm{U}$ ratios of the zircons $(0.22-0.83 ; \mathrm{Tab} .2)$, with an average value of 0.34 for the most concordant spots, indicate that these zircons are magmatic. The results provided an upper intercept age of $2929 \pm 7.0[ \pm 11] \mathrm{Ma}$ (mean square weighted deviation $-M S W D=0.82$ ) (Fig. 9). Ten zircon grains with concordance between 90 and $100 \%$ yielded $\mathrm{a}^{207} \mathrm{~Pb} /{ }^{206} \mathrm{~Pb}$ weighted mean age of 2913.6 $\pm 6.9 \mathrm{Ma}(\mathrm{MSWD}=0.73$; probability of concordance $=0.69$ ). The concordia age of $2917.5 \pm 9.2(\mathrm{MSWD}=0.083$; probability of concordance $=0.77)$ was calculated based on the results of five analyses and coincides (within error) with the upper intercept age; it is interpreted to represent the crystallization age of the PUp granodiorite (Fig. 9). The lower intercept age of $533 \pm 25 \mathrm{Ma}$ is interpreted to be related to lead loss, i.e., to the opening of the U-Th- $\mathrm{Pb}$ system during the construction of the Araçuaí orogen in the Brasiliano event (Neoproterozoic). An interesting feature of these samples is the absence of inherited zircons.

\section{Zircon and apatite saturation temperatures}

The initial temperatures of silicate magmas can be estimated using the zircon saturation thermometry method (TZr) (Watson \& Harrison 1983). Experimental studies have shown that the solubility of zircon in a felsic and not peralkaline magma depends almost exclusively on the temperature and composition of the magma, especially in relation to its concentrations of $\mathrm{Na}, \mathrm{K}, \mathrm{Ca}, \mathrm{Al}, \mathrm{Si}$ and $\mathrm{Zr}$; the effects exerted by pressure can be considered to be insignificant. Here, TZr were calculated from whole rock following the approach of Watson and Harrison (1983) $\left(\mathrm{TZ}_{\mathrm{W}_{\mathrm{Q} H \mathrm{H}}}\right)$ and the recalibration by Boehnke et al. (2013) $\left(\mathrm{TZr}_{\mathrm{B}}\right)$ (Tab. 1). The mean $\mathrm{TZr}_{\mathrm{W} \& \mathrm{H}}$ values obtained from the PUp, RGp and BAp are 797,745 and $739^{\circ} \mathrm{C}$, respectively. $\mathrm{TZr}_{\mathrm{B}}$ is relatively low, with mean values of 753,698 and $686^{\circ} \mathrm{C}$ for the PUp, RGp and BAp, respectively. The absence of inherited zircons indicates that the magma was undersaturated at the source, and, therefore, the calculated zircon saturation temperatures represent minimum temperatures (Miller et al. 2003). Thus, the magmas from which these rocks were originated could have reached higher temperatures, and the obtained zircon saturation temperatures indicate the minimum temperature of these magmas.

Apatite saturation temperatures (TAp) are calculated as a function of $\mathrm{SiO}_{2}$ content in melt composition and the distribution coefficient of phosphorus between apatite and melt (following Harrison \& Watson 1984). As apatite show elevated solubility in peraluminous granitic melts, the correction proposed by Bea et al. (1992) was used to avoid overestimated temperatures. The TAp is slightly higher than $T Z r$, suggesting earlier apatite saturation. Much like the TZr, TAp are higher for PUp (with a mean temperature of $857^{\circ} \mathrm{C}$ ) than RGp and BAp (with mean TAp at 781 and $764^{\circ} \mathrm{C}$, respectively). 

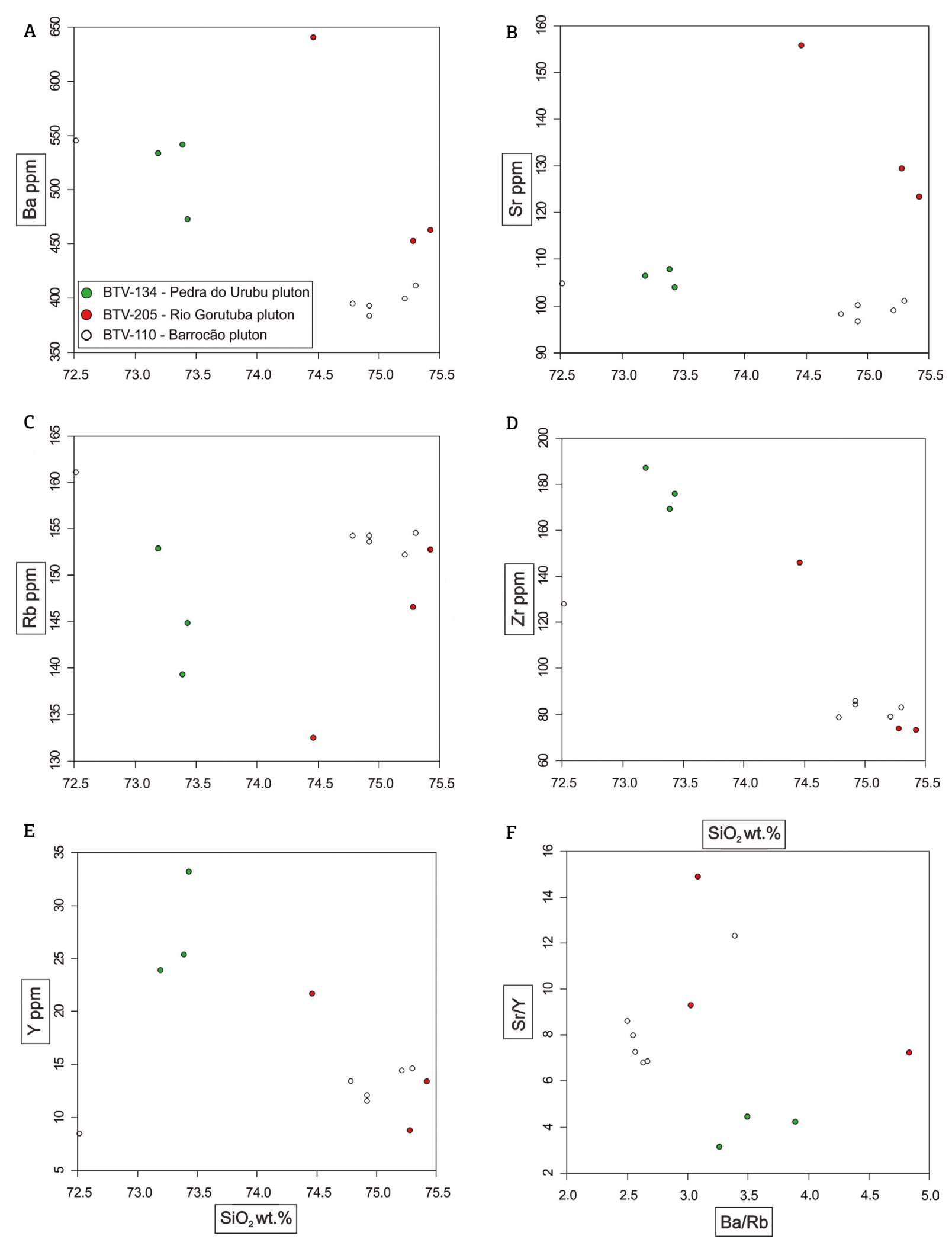

Figure 7. Trace elements Harker diagram of the Pedra do Urubu (PUp), Rio Gorutuba (RGp) and Barrocão (BAp) granitoids. 


\section{DISCUSSION}

\section{The Archaean plutonic bodies of the Itacambira-Monte Azul block}

The PUp, RGp and BAp rocks have several similar characteristics, such as their high silica contents, similar $\mathrm{Na}_{2} \mathrm{O}$ values, weakly peraluminous characteristics, low $\mathrm{Mg} \#$ values, and relative enrichment in LILE over HFSE, as well as the negative Eu anomalies and negative peaks in $\mathrm{Ba}, \mathrm{Nb}, \mathrm{P}$ and Ti observed on primitive mantle-normalized spider diagrams (Figs. 6, 7 and 8; Tab. 1). However, although all of the studied pluton samples plot in the field of high-potassium rocks on the Gill (1981) diagram (Fig. 5C), the BAp syenogranites are more enriched in potassium (with $\mathrm{K}_{2} \mathrm{O}$ / $\mathrm{Na}_{2} \mathrm{O}$ ratios ranging from 1.55 to 1.88 ) and depleted in
A
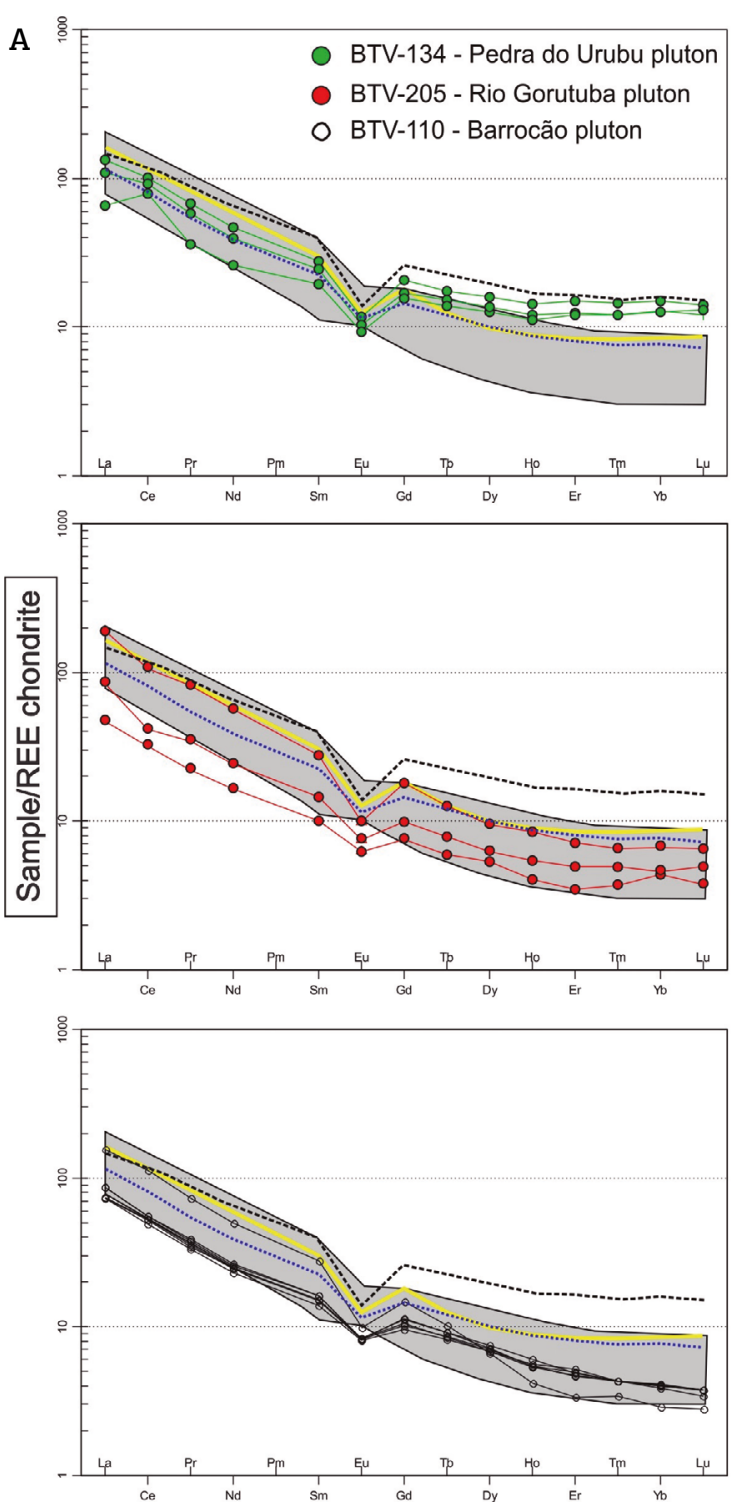

B
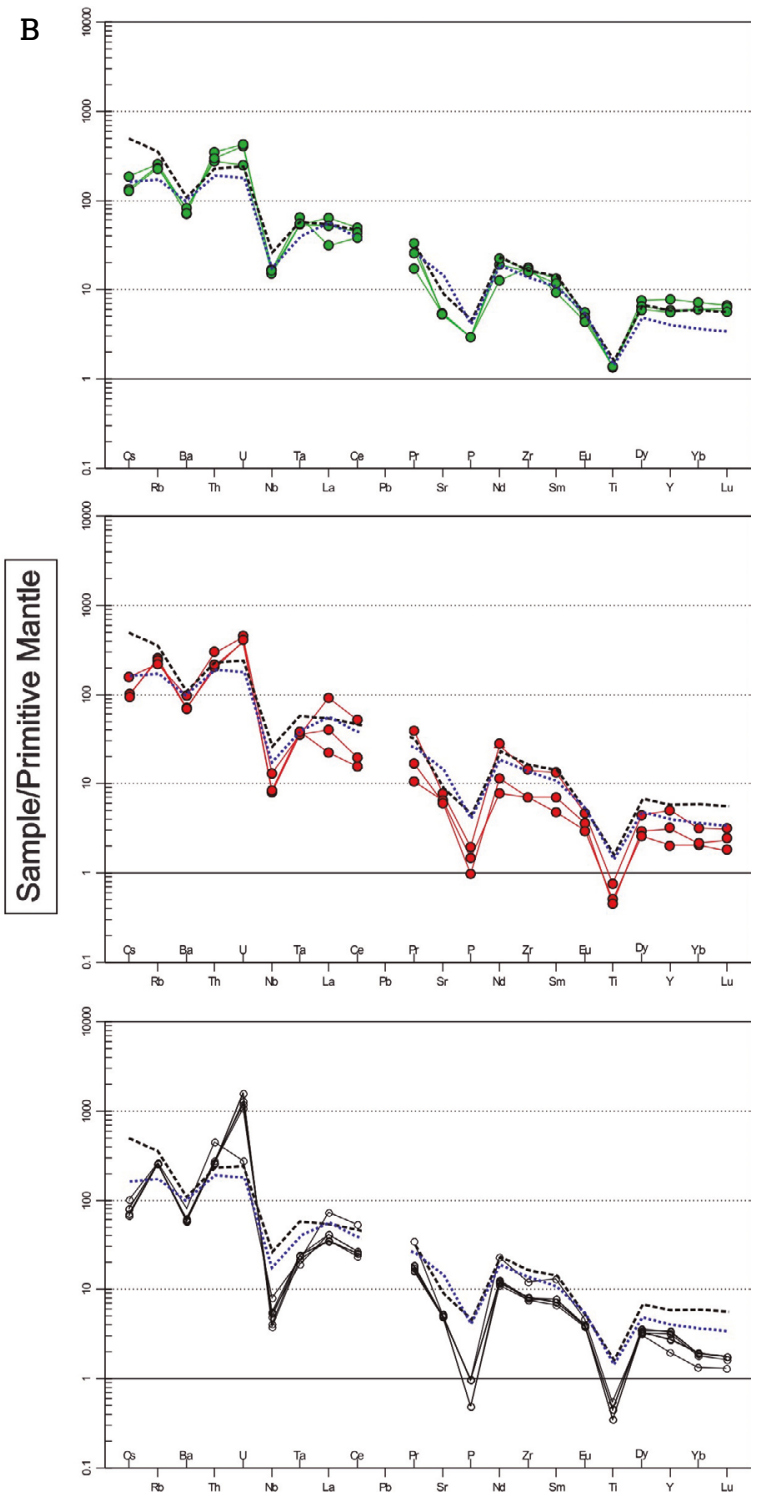

REE: rare earth element.

Figure 8. (A) Chondrite-normalized rare earth element patterns. (B) Primitive mantle-normalized trace element spidergrams for the Pedra do Urubu (PUp), Rio Gorutuba (RGp) and Barrocão (BAp) granitoids. Normalized values for chondrite are from Boynton (1984) and for primitive mantle from McDonough and Sun (1995). The gray field reflects the compositions of the TTGs from Moyen (2011). The solid yellow line indicates the granodioritic protolith from Carvalho et al. (2016). The black dashed line indicates the average composition of the kfs-bearing granitoids from Farina et al. (2015). The blue dashed line indicates the average composition of the transitional TTGs from Farina et al. (2015). 
$\mathrm{CaO}$ and ferromagnesian oxides relative to the rocks of PUp and $\mathrm{RGp}$, which record relatively lower $\mathrm{K}_{2} \mathrm{O} / \mathrm{Na}_{2} \mathrm{O}$ ratios (between 0.84 and 1.06) for the same range of $\mathrm{SiO}_{2}$ values. Therefore, the studied rocks can be separated into two groups based on their $\mathrm{K}_{2} \mathrm{O} / \mathrm{Na}_{2} \mathrm{O}$ ratios (Tab. 1): the rocks of the BAp are classified in a group that is highly enriched in potassium, whereas the PUp and RGp rocks are classified in a medium-potassium group with $\mathrm{K}_{2} \mathrm{O} / \mathrm{Na}_{2} \mathrm{O}$ ratios that are close to one (Fig. 6E).

On the magmatic series classification diagram proposed by Frost et al. (2001), the rocks of the medium- and high-potassium groups plot in different fields (Fig. 5E). According to Frost et al. (2001), rocks of the same magmatic suite tend to exhibit subparallel trends during the differentiation of the source magma. According to the authors, this feature may occur due to a high degree of magmatic differentiation. The results show that the studied plutons already have a high differentiation index, as they record $\mathrm{SiO}_{2}$ contents that are higher than $72 \mathrm{wt} \%$. The $\mathrm{K}_{2} \mathrm{O} / \mathrm{Na}_{2} \mathrm{O}$ and $\mathrm{FeOt}+\mathrm{MgO}$ versus $\mathrm{SiO}_{2}$ diagrams indicate that it is unlikely that the process of magmatic differentiation was responsible for the lithochemical differences observed between the mediumand high-potassium groups (Figs. 6E and 6F). On these diagrams, it is possible to observe a clear correlation between the results of the PUp and RGp samples, which suggests that these rocks experienced the same magmatic evolution.

Table 2. U-Pb-Th isotope analyses and age of zircon grains from the BTV-134 Pedra do Urubu granodiorite sample.

\begin{tabular}{|c|c|c|c|c|c|c|c|c|c|c|c|c|c|c|}
\hline \multirow{2}{*}{ Spot } & \multirow{2}{*}{ Th/U } & \multicolumn{6}{|c|}{204 corrected ratios } & \multicolumn{6}{|c|}{204 corrected ages $(\mathrm{Ma})$} & \multirow{2}{*}{ Conc } \\
\hline & & $207 * / 206 *$ & $2 s$ & $206 * / 238$ & $2 s$ & $207 * / 235$ & $2 \mathrm{~s}$ & $207 / 206^{*}$ & $2 s$ & $206 * / 238$ & $2 s$ & $207 * / 235$ & $2 s$ & \\
\hline Spot PUp 1 & 0.29 & 0.2133 & 1.6594 & 0.5707 & 1.6977 & 16.7826 & 2.3740 & $2,930.63$ & 26.83 & $2,910.69$ & 39.89 & $2,922.49$ & 23.01 & 99.60 \\
\hline Spot PUp 2 & 0.22 & 0.2105 & 1.5238 & 0.5720 & 1.5667 & 16.6010 & 2.1855 & $2,909.25$ & 24.69 & $2,916.15$ & 36.86 & $2,912.07$ & 21.15 & 100.14 \\
\hline Spot PUp 3 & 0.39 & 0.2032 & 1.1072 & 0.4217 & 1.1856 & 11.8160 & 1.6222 & $2,852.15$ & 18.03 & $2,268.28$ & 22.71 & $2,589.93$ & 15.30 & 87.58 \\
\hline Spot PUp 4 & 0.83 & 0.1992 & 1.3624 & 0.3854 & 1.3880 & 10.5848 & 1.9449 & $2,819.41$ & 22.25 & $2,101.65$ & 24.94 & $2,487.38$ & 18.21 & 84.49 \\
\hline Spot PUp 5 & 0.47 & 0.1872 & 1.2232 & 0.2956 & 1.3059 & 7.6303 & 1.7892 & $2,717.89$ & 20.16 & $1,669.40$ & 19.23 & $2,188.44$ & 16.19 & 76.28 \\
\hline Spot PUp 6 & 0.27 & 0.2107 & 1.5909 & 0.5053 & 1.3724 & 14.6791 & 2.1011 & $2,910.94$ & 25.77 & $2,636.45$ & 29.77 & $2,794.67$ & 20.17 & 94.34 \\
\hline Spot PUp 7 & 0.35 & 0.2106 & 1.4577 & 0.5082 & 1.3157 & 14.7592 & 1.9637 & $2,910.51$ & 23.61 & $2,648.81$ & 28.64 & $2,799.84$ & 18.85 & 94.61 \\
\hline Spot PUp 8 & 0.36 & 0.2112 & 1.1425 & 0.5720 & 1.1816 & 16.6556 & 1.6436 & $2,914.69$ & 18.50 & 2,915.99 & 27.78 & $2,915.22$ & 15.87 & 100.03 \\
\hline Spot PUp 9 & 0.38 & 0.2115 & 1.0639 & 0.5240 & 1.1870 & 15.2800 & 1.5940 & $2,917.00$ & 17.22 & $2,716.12$ & 26.36 & $2,832.85$ & 15.31 & 95.88 \\
\hline Spot PUp 10 & 0.35 & 0.2029 & 1.0779 & 0.4212 & 1.1832 & 11.7844 & 1.6006 & $2,849.95$ & 17.56 & $2,265.74$ & 22.64 & $2,587.42$ & 15.09 & 87.57 \\
\hline Spot PUp 11 & 0.63 & 0.1865 & 1.5357 & 0.2917 & 1.3523 & 7.5004 & 2.0463 & $2,711.48$ & 25.33 & $1,649.97$ & 19.72 & $2,173.04$ & 18.50 & 75.93 \\
\hline Spot PUp 12 & 0.35 & 0.2005 & 1.5507 & 0.3657 & 1.3866 & 10.1087 & 2.0803 & $2,830.05$ & 25.30 & $2,009.18$ & 23.98 & $2,444.76$ & 19.41 & 82.18 \\
\hline Spot PUp 13 & 0.34 & 0.1914 & 1.6683 & 0.3076 & 1.4363 & 8.1201 & 2.2014 & $2,754.56$ & 27.41 & $1,729.03$ & 21.82 & $2,244.48$ & 20.10 & 77.03 \\
\hline Spot PUp 14 & 0.41 & 0.2120 & 1.1842 & 0.5727 & 1.1979 & 16.7369 & 1.6844 & $2,920.59$ & 19.17 & $2,918.86$ & 28.18 & $2,919.88$ & 16.27 & 99.96 \\
\hline Spot PUp 15 & 0.29 & 0.1963 & 1.4518 & 0.3427 & 1.3073 & 9.2759 & 1.9536 & $2,795.76$ & 23.76 & $1,899.65$ & 21.54 & $2,365.64$ & 18.07 & 80.30 \\
\hline Spot PUp 16 & 0.42 & 0.2123 & 1.6398 & 0.5718 & 1.4278 & 16.7343 & 2.1743 & $2,922.83$ & 26.53 & $2,915.25$ & 33.57 & $2,919.74$ & 21.05 & 99.85 \\
\hline Spot PUp 17 & 0.32 & 0.1749 & 1.1321 & 0.2455 & 1.1567 & 5.9210 & 1.6185 & $2,605.09$ & 18.86 & $1,415.38$ & 14.72 & $1,964.32$ & 14.16 & 72.05 \\
\hline Spot PUp 18 & 0.44 & 0.1964 & 1.5403 & 0.3588 & 1.2866 & 9.7157 & 2.0070 & $2,796.66$ & 25.21 & $1,976.25$ & 21.94 & $2,408.20$ & 18.65 & 82.06 \\
\hline Spot PUp 19 & 0.40 & 0.1947 & 1.2110 & 0.3440 & 1.1825 & 9.2319 & 1.6925 & $2,781.95$ & 19.84 & $1,905.69$ & 19.54 & $2,361.28$ & 15.63 & 80.71 \\
\hline Spot PUp 20 & 0.27 & 0.2034 & 2.2786 & 0.4261 & 1.8489 & 11.9473 & 2.9344 & $2,853.36$ & 37.10 & $2,288.07$ & 35.71 & $2,600.28$ & 27.87 & 87.99 \\
\hline Spot PUp 21 & 0.28 & 0.2083 & 1.5297 & 0.4663 & 1.3075 & 13.3917 & 2.0124 & $2,892.14$ & 24.82 & $2,467.49$ & 26.86 & $2,707.67$ & 19.19 & 91.13 \\
\hline Spot PUp 22 & 0.29 & 0.1817 & 1.5974 & 0.1358 & 1.8444 & 3.4026 & 2.4400 & $2,668.28$ & 26.45 & 821.04 & 14.23 & $1,504.99$ & 19.33 & 54.55 \\
\hline Spot PUp 23 & 0.19 & 0.1387 & 2.1212 & 0.0880 & 2.9215 & 1.6820 & 3.6104 & $2,210.93$ & 36.80 & 543.46 & 15.24 & $1,001.75$ & 23.26 & 54.25 \\
\hline Spot PUp 24 & 0.42 & 0.2101 & 1.2176 & 0.5249 & 1.1925 & 15.2079 & 1.7043 & $2,906.53$ & 19.73 & $2,719.97$ & 26.52 & $2,828.35$ & 16.37 & 96.17 \\
\hline Spot PUp 25 & 0.41 & 0.2019 & 1.2430 & 0.4078 & 1.1966 & 11.3546 & 1.7254 & $2,841.86$ & 20.26 & $2,204.95$ & 22.38 & $2,552.70$ & 16.23 & 86.38 \\
\hline
\end{tabular}

PUp: Pedra do Urubu. 
However, no relationship with BAp can be established, since at the same $\mathrm{SiO}_{2}$ concentration, the concentration of $\mathrm{K}_{2} \mathrm{O}$ is much higher. Thus, the hypothesis that the rocks belonging to the high-potassium group resulted from the extreme differentiation of the same source magma as the medium-potassium rocks can be discarded. In this case, it is possible to assume that the granitoids in the medium- and high-potassium groups are related to different magmatic sources.

The U-Pb crystallization age obtained for the PUp granodiorite, $2917.5 \pm 9.2 \mathrm{Ma}$ (Fig. 9), indicates that the rocks of the medium-potassium group were formed by an important magmatic event that reached the BIMA during the Mesoarchean. In this work, the U-Pb dating of the high-potassium-group rocks was not performed. However, Silva et al. (2016) obtained a crystallization age of $2657 \pm$ $25 \mathrm{Ma}$ (U-Pb SHRIMP) for a syenogranite of the BAp. The $\mathrm{K}_{2} \mathrm{O} / \mathrm{Na}_{2} \mathrm{O}$ ratio (1.6) of this syenogranite is similar to that of the high-potassium group defined in this work. Considering this age to represent the crystallization age of the entire high-potassium group, it is clear that the genesis of the medium- and high-potassium groups should be distinct, as it is expected based on the interpretation of the

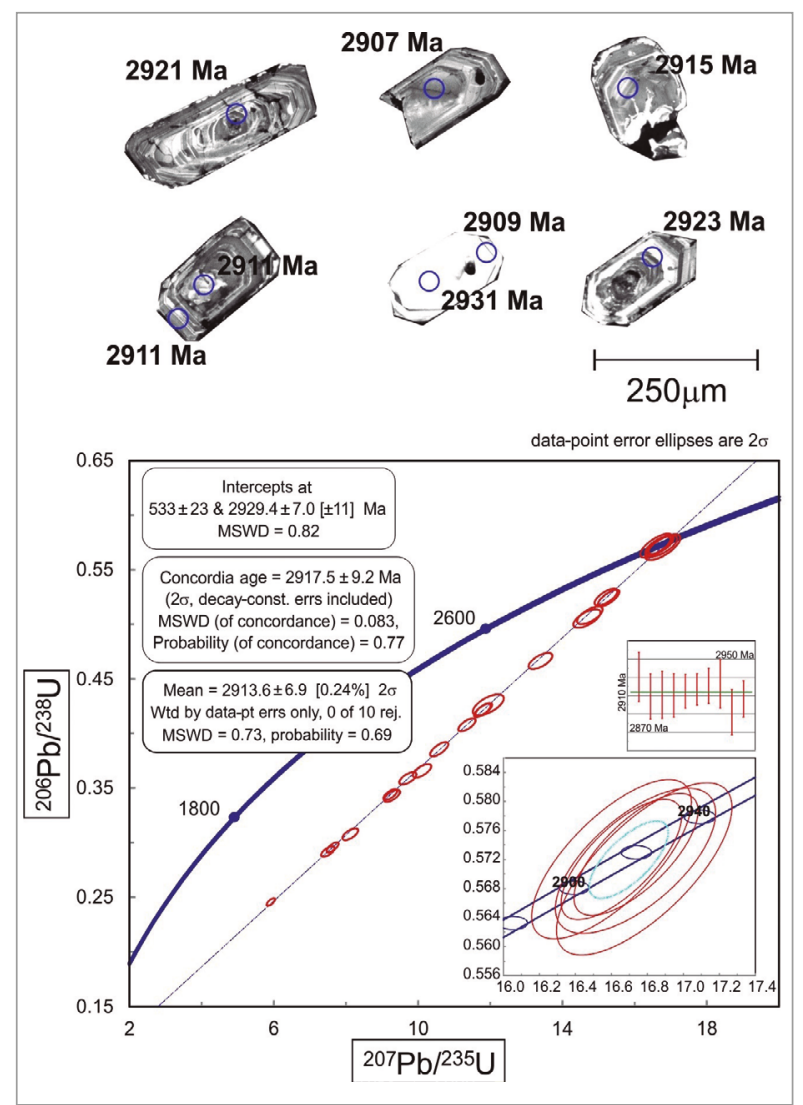

Figure 9. Cathodoluminescence images, zircon $\mathrm{U}-\mathrm{Pb}$ Concordia plot and $207 \mathrm{~Pb} / 206 \mathrm{~Pb}$ weighted mean ages from the BTV-134 PUp sample. lithochemical data. This interpretation suggests that the BIMA records at least two magmatic events that generated potassic granitoids: one occurred during the Mesoarchean and the other occurred during the Neoarchean. In addition, the lower intercept ages obtained for the PUp, at $533 \pm 25 \mathrm{Ma}$, and BAp, at $622 \pm 68 \mathrm{Ma}$ (Silva et al. 2016), indicate that these rocks were affected by the Brasiliano event during the evolution of the Araçuaí orogen.

\section{Classification and petrogenesis of the Pedra do Urubu, Rio Gorutuba and Barrocão plutons}

When comparing the geochemical signatures of the granitoids studied here with those of the main Archean plutonic lithotypes, it can be noted that the rocks of the PUp, RGp and BAp do not resemble the series of TTG rocks, since their values of $\mathrm{K}_{2} \mathrm{O} / \mathrm{Na}_{2} \mathrm{O}(0.84-1.88)$ and $\mathrm{K} / \mathrm{Na}(0.55-1.24)$ are higher than those expected for typical TTGs, which tend to be less than 0.5 and 0.3, respectively (Moyen 2011, Moyen \& Martin 2012). The low Sr/Y ratios (between 3 and 15), the low degree of enrichment of LREE relative to HREE $\left(\mathrm{La}_{\mathrm{N}} / \mathrm{Yb}_{\mathrm{N}}\right.$ values between 5.17 and 28.76), the moderate to high negative $\mathrm{Eu}$ anomalies $\left(\mathrm{Eu} / \mathrm{Eu}^{*}\right.$ values between 0.49 and 0.70 ) and the Sr negative anomalies of these granites also contrast with the signatures of TTGs. However, some characteristics resemble those of TTGs, such as the negative anomalies of $\mathrm{Nb}, \mathrm{Ta}, \mathrm{P}$ and $\mathrm{Ti}$ observed on the primitive mantle-normalized diagrams. The absence of mafic microgranular enclaves, the low concentrations of ferromagnesian oxides, $\mathrm{Ba}, \mathrm{Sr}$ and transition elements, and the low $\mathrm{Ba} / \mathrm{Rb}$ ratios $(<4)$ obtained in these rocks are incompatible with the signatures of the sanukitoid granitoid series (Shirey $\&$ Hanson 1984, Martin et al. 2009) and the Closepet granites (Moyen et al. 2003).

Both the BAp syenogranites and the PUp and RGp granodiorites and monzogranites are enriched in silica and potassium, with $\mathrm{K}_{2} \mathrm{O} / \mathrm{Na}_{2} \mathrm{O}$ ratios that are always higher than 0.8; they are also depleted in ferromagnesian oxides $\left(\mathrm{FeO}_{\mathrm{T}}+\mathrm{MgO}+\mathrm{TiO}_{2}+\mathrm{MnO}<3 \mathrm{wt} \%\right)$ and calcium $(\mathrm{CaO}<1.8 \mathrm{wt} \%)$. In addition, these rocks show negative Eu anomalies, low to moderate degrees of REE fractionation and relative enrichment in LILE and the depletion of HFSE and transition elements. These characteristics, in addition to the absence of primary muscovite, are similar to those described in highly potassic biotite granite signatures in several Archean blocks around the world (e.g., Moyen et al. 2003, Champion \& Smithies 2007, Feio et al. 2013, Mikkola et al. 2012, Almeida et al. 2013, Laurent et al. 2014, Farina et al. 2015, Fu et al. 2017).

Figures $10 \mathrm{~A}$ and $10 \mathrm{~B}$ present the ternary classification diagrams for Archean granitoids proposed by Laurent 
et al. (2014) and Moyen et al. (2003). On both diagrams, the rocks of the high-potassium group, which are represented by the BAp syenogranites, plot in the biotite granites field. The medium-potassium group granitoids also plot in the biotite granites fields. However, on both diagrams, these

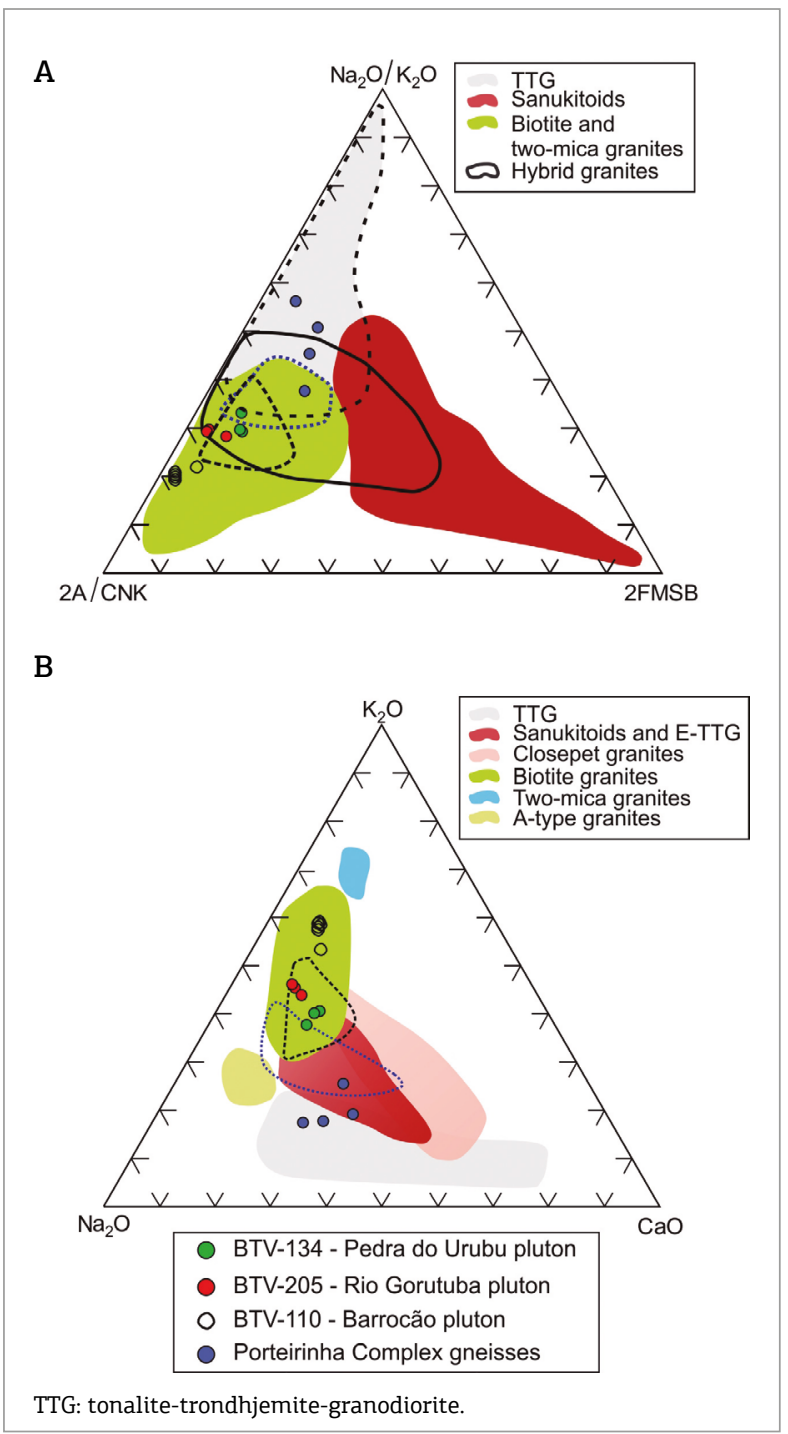

Figure 10. (A) Ternary classification diagram for Archean granitoids proposed by Laurent et al. (2014). The vertices of the diagram are: $2 * \mathrm{~A} / \mathrm{CNK}$ (molar $\mathrm{Al}_{2} \mathrm{O}_{3} /$ $\left(\mathrm{CaO}+\mathrm{K}_{2} \mathrm{O}+\mathrm{Na}_{2} \mathrm{O}\right) ; \mathrm{Na}_{2} \mathrm{O} / \mathrm{K} 2 \mathrm{O} ; 2^{*}(\mathrm{FeOtot}+\mathrm{MgO})^{*}(\mathrm{Sr}$ $+\mathrm{Ba})$ wt. $\mathrm{Ba}$ and $\mathrm{Sr}$ concentrations used for the classification of the Porteirinha Complex gneisses are from the mean of the TTGs according to Moyen and Martin (2012), since only the major oxide results were available for these samples. (B) Ternary classification diagram for Archean granitoids proposed by Moyen et al. (2003). The black dashed line indicates the average composition of the kfs-bearing granitoids from Farina et al. (2015). The blue dashed line indicates the average composition of the transitional TTGs from Farina et al. (2015). rocks plot in regions where the overlapping of distinct fields occurs. In the Laurent et al. (2014) diagram, these rocks plot in the overlapping region between the fields of the biotite granites and hybrid granites, whereas in the Moyen et al. (2003) diagram, they plot where the field of biotite granites overlaps the field of sanukitoids and enriched TTGs. As previously discussed, the classification of these rocks as TTGs or sanukitoids can be ruled out. Thereby, since there is no evidence of magma mixing or mingling which would make it possible to classify the medium-potassium group rocks as hybrid granitoids, these rocks are also classified as high-K biotite granites.

The origin of the Archean high-potassium granites is commonly attributed to the reworking of ancient continental crust. Some works have suggested the participation of mantle material in the source of these granites (Ridley et al. 1997, Whalen et al. 2004). If these rocks had a mantle-enriched source, they should have higher $\mathrm{Mg \#}$ values and higher values of $\mathrm{CaO}, \mathrm{MgO}+\mathrm{FeOt}$, LILE (mainly $\mathrm{Ba}$ and $\mathrm{Sr}$ ), V, Ni and Cr. Thus, it is unlikely that the granitoids analyzed in this work could be related to materials of mantle origin. The partial melting of meta-mafic rocks has also been proposed as a probable source for these granitoids. Experimental studies have shown that the products of the partial melting of low-K mafic rocks are not as enriched in $\mathrm{K}_{2} \mathrm{O}$, with lower concentrations than those obtained here for the high- and medium-potassium groups (Beard \& Lofgren 1991, Rapp \& Watson 1995). Sisson et al. (2005) show that the partial melting of medium-to-high-K basaltic rocks may produce granitoids enriched in potassium. However, as present in the ternary classification diagram of Figure 11, the granitoids of PUp, RGp, BAp plot away from the field of granitoids originated by partial melting of high-K mafic rocks.

As highlighted by Laurent et al. (2014), several studies have suggested that the genesis of biotite granite is related to the partial melting of rocks with TTG signatures (e.g., Martin et al. 1997, Champion \& Sheraton 1997, Whalen et al. 2004, Frost et al. 2006, Manya et al. 2007, Dey et al. 2012, Mikkola et al. 2012, Almeida et al. 2013, Manya 2016). Such interpretations have been corroborated by experimental modeling studies in which high-potassium granitoids were generated from the partial melting of tonalites (with or without the presence of fluids) (Skjerlie \& Johnston 1992, Skjerlie et al. 1993, Castro 2004, Patińo Douce 2005, Watkins et al. 2007). In these experiments, the results of partial melting depend on both the composition of the starting material and the experimental conditions.

The ternary diagrams in Figures 5B, 11A and 11B illustrate the relationship between the granitoids of the mediumand high-potassium groups in this work and the granite 


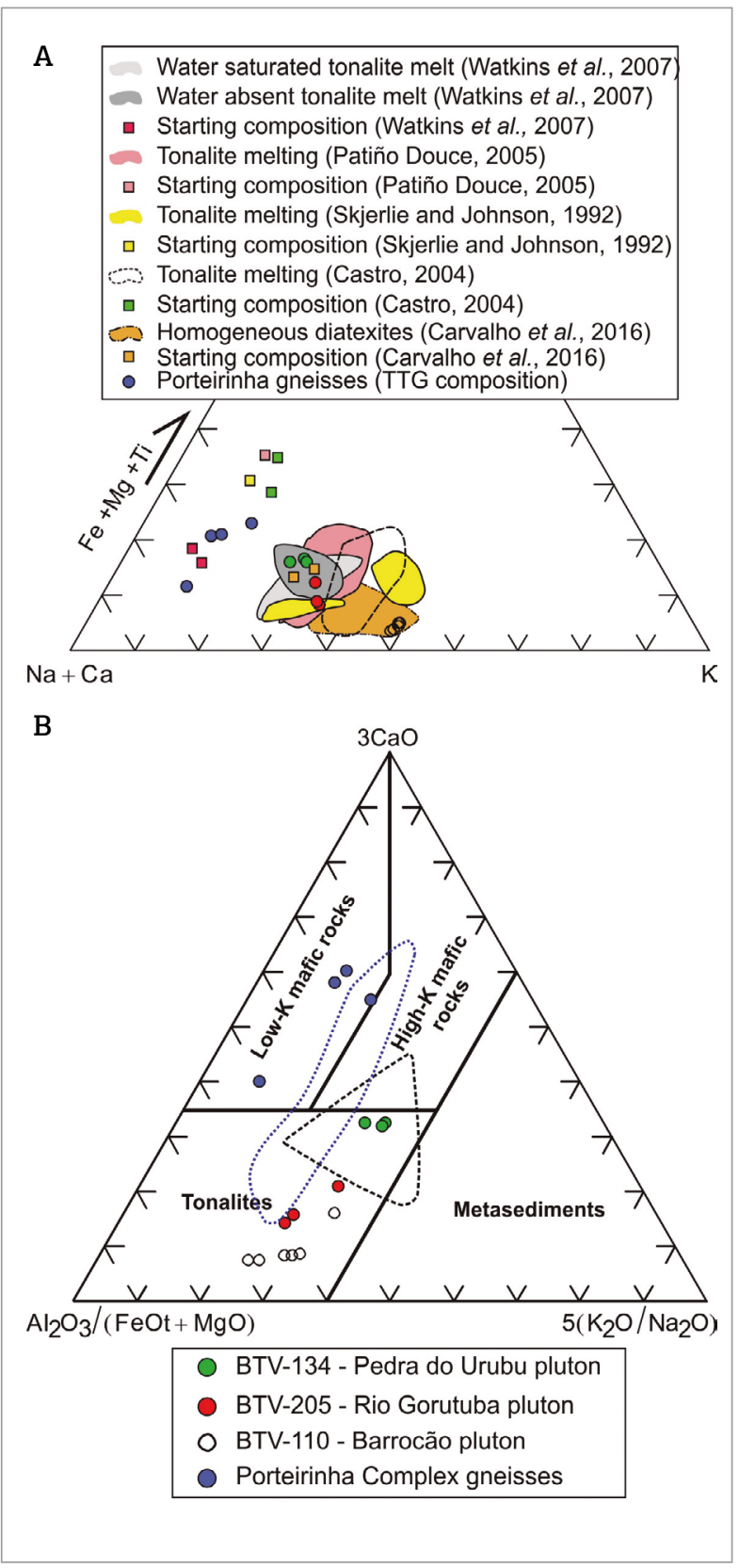

Figure 11. (A) Ternary diagram (from Farina et al. 2015) with comparison between the compositions of the high and medium potassium groups granitoids and the compositions of experimental glasses generated by the partial melting of tonalitic and granodiorite rocks. (B) Ternary diagram proposed by Laurent et al. (2014) for classification of potential magmatic sources for Archean granitoids. The fields represent the composition of magmas derived from several potential sources (Laurent et al. 2014, for references). The black dashed line indicates the average composition of the kfsbearing granitoids from Farina et al. (2015). The blue dashed line indicates the average composition of the transitional TTGs from Farina et al. (2015). fields generated by the partial melting of tonalities in various experimental studies. In these figures, the reference materials used in several experimental works and the lithochemical results of the TTG gneisses of the Porteirinha Complex, which are the country rocks of the BAp, PUp and RGp rocks, are also plotted for comparison purposes. In these figures, the granitoids of the medium-potassium group plot in the field of the experimental results obtained by Watkins et al. (2007) and Patińo Douce (2005) for the fluid-absent partial melting of tonalites. It is noted that the compositions of two TTG samples from the Porteirinha Complex are very close to the composition of one of the reference materials used by Watkins et al. (2007). The reference material used by Patiño Douce (2005) has a composition that is quite different than that of the TTGs of the Porteirinha Complex. Thus, the experimental results obtained by Patiño Douce (2005) cannot be used to explain the genesis of these rocks.

According to Watkins et al. (2007), tonalities with $\mathrm{K}_{2} \mathrm{O}$ / $\mathrm{Na}_{2} \mathrm{O}$ ratios of $<0.34$ may not be fertile enough to generate potassic granitoids. In this work, the partial melting of tonalites with $\mathrm{K}_{2} \mathrm{O} / \mathrm{Na}_{2} \mathrm{O}$ ratios between 0.29 and 0.34 produced melts with $\mathrm{K}_{2} \mathrm{O} / \mathrm{Na}_{2} \mathrm{O}$ ratios between 0.39 and 1.51 . The $\mathrm{K}_{2} \mathrm{O} / \mathrm{Na}_{2} \mathrm{O}$ ratios of the Porteirinha Complex TTGs range from 0.31 to 0.54 ; they may thus be sufficiently fertile for the production of the less differentiated granitoids of the medium-potassium group, the ratios of which vary between 0.84 and 1.0. Nevertheless, as the Porteirinha TTG gneisses represent the country rock of the studied granitoids, it is difficult to think they are also the source of these granitic magmas. Therefore, the source rock of the studied rocks could be similar in composition to the Porteirinha gneisses. The significant negative Eu anomalies and the low $\mathrm{Sr} / \mathrm{Y}$ ratios of the samples of the medium-potassium group indicate the retention of plagioclase at the source, which is consistent with the results of Watkins et al. (2007), who observed a plagioclase-rich residual assemblage after partial melting. The retention of the plagioclase at the source, coupled with the low fractionation of REE and the low concentrations of $\mathrm{Sr}$, indicate low-pressure conditions at the source (Watkins et al. 2007). The mean TAp and $\mathrm{TZr}_{\mathrm{W} \& \mathrm{H}}$ values obtained for the PUp rocks vary between ca. 857 and $797^{\circ} \mathrm{C}$, respectively, and are slightly lower than the temperatures required for the partial melting of TTGs under anhydrous conditions (Skjerlie \& Johnston 1992, Castro 2004, Patińo Douce 2005, Watkins et al. 2007). However, as discussed earlier, these are the estimated minimum temperatures for the initial magma temperatures. Thus, the initial temperature of the PUp could have reached the necessary temperatures required for the partial melting of TTGs under anhydrous conditions. Moreover, the presence of perthitic microcline and interstitial biotite suggests relatively 
anhydrous conditions at high temperatures (Philpotts 1990, Misra et al. 2017). These data indicate that the PUp granitoids originated from the partial melting of TTGs, whose signatures are similar to the Porteirinha Complex gneisses, under conditions of relatively low pressures and high temperatures. The fractionation of this magma would have generated the RGp granitoids. The PUp samples show major oxide concentrations that are comparable to those of the RGp, but tend to be more enriched in REE and have more pronounced negative $\mathrm{Eu}$ anomalies. As the partition coefficients of the REE (with the exception of $\mathrm{Eu}$ ) for the main mineralogy of these rocks are very low, it is probable that the fractionation of accessory minerals exerted a strong control on this variation. In fact, the decreases in the modal proportions of magmatic epidote, allanite, titanite and zircon between the PUp and RGp rocks are remarkable. The decrease in the TAp and TZr values from PUp to RGp indicates that the fractionation of these accessory mineral phases controlled this variation in REE concentrations between the rocks of the medium-potassium group. Recently, Fu et al. (2017) concluded from a geochemical modeling study that the fractionation of accessory mineral phases, such as titanite, allanite, epitote, apatite and zircon, can lead to a decrease in REE concentrations during the fractional crystallization of a single magma.

As observed from the rocks of the medium-potassium group, the syenogranites of the high-potassium group record restricted chemical variations at high levels of $\mathrm{SiO}_{2}$. In the diagram in Figure 5B, the high-potassium-group rocks plot in the fields of the experimental results obtained by Castro (2004) and Patińo Douce (2005) and close to the field of Skjerlie and Johnston (1992). However, these experimental results are enriched in potassium and depleted in ferromagnesian oxides compared to the results obtained in this study (Figure 11A). The $\mathrm{K}_{2} \mathrm{O} / \mathrm{Na}_{2} \mathrm{O}$ ratios of this group vary between 1.55 and 1.88 and are thus higher than the maximum ratio of 1.51 obtained in the experiments of Watkins et al. (2007). The Tap and TZr values of these samples are relatively low (mean at 764 and $739^{\circ} \mathrm{C}$, respectively) and match the temperature range of the experiments controlled by the presence of fluids (Castro 2004, Patińo Douce 2005, Watkins et al. 2007). Nevertheless, the melts generated in the fluid-present partial melt experiments show even lower $\mathrm{K} 2 \mathrm{O} / \mathrm{Na}_{2} \mathrm{O}$ ratios. Thus, the partial melting of rocks that share similar signature with the Porteirinha TTG gneisses, under anhydrous or hydrated conditions, would not be fertile enough to generate the rocks of the high-potassium group. The partial melting of metasedimentary rocks could explain the high concentrations of potassium in these rocks. The absence of primary aluminum-rich minerals and the isotopic signature obtained by Silva et al. (2016) for a sample of the high-potassium group, which has a weakly negative $\varepsilon N d$ value (-2.66) and a TDM of $3.28 \mathrm{Ga}$, is not consistent with a metasedimentary source, as more negative $\varepsilon \mathrm{Nd}$ values would be expected in that case. Silva et al. (2016) assigned a mixed source to these rocks. However, no field, petrographic and/or geochemical evidences of magma mixing in the generation of these rocks were observed. Recently, in a study of the reworking of granitic continental crust, Carvalho et al. (2016) showed that the partial melting (migmatization) of a protolith with a signature similar to that of the medium-potassium-group granitoids (Figs. 5B, 9 and $11 \mathrm{~A}$ ), under temperature and pressure conditions of $736^{\circ} \mathrm{C}$ and 5.1 to $6.1 \mathrm{kbar}$, respectively, with the participation of aqueous fluids, can produce large volumes of diatextic rocks with signatures similar to those obtained for the rocks of the high-potassium group. Thus it is possible that the generation of the high-potassium granitoids results directly from the fluid-present partial melting of the medium-potassium Mesoarchean granitoids.

\section{New lithodemic classification for the Pedra do Urubu, Rio Gorutuba and Barrocão plutons}

As defined by the International Stratigraphic Guide (Salvador 1994), the term "Suite" should be used to group two or more lithodemic units of the same class; in the case of plutonic granitoid rocks, these units should share common lithologic features. Chappell (1984) described that the same igneous suite should encompass rocks that, in addition to sharing common lithologic aspects, also have the same chemical and isotopic natures. Taking into account these concepts and the results obtained in the scope of this work, the lithodemic classification of the Rio Itacambiruçu Suite proposed by Grossi-Sad et al. (1997), which encompasses the PUp, RGp, and BAp, does not meet all the requirements for such classification because, although these plutons share common lithologic aspects, some of their genetic and geochronological aspects are different. Our geochemical results allow us to subdivide these granitoids into the medium- and high-potassium groups. In addition, the geochronological results show that these groups have different crystallization ages. Therefore, we propose that the rocks of the medium-potassium group can be inserted in the Pedra do Urubu Suite, thus preserving the name proposed by Guimarães et al. (1993), and the rocks of the high-potassium group should be integrated into the Barrocão Suite. In order to not discard the term "Rio Itacambiruçu", which is already consecrated in the literature, we propose naming it "Rio Itacambiruçu Supersuite", integrating the Archean potassic granitoids with calc-alkaline signatures of the Pedra do Urubu and Barrocão suites. 


\section{Considerations on the crustal evolution of the Itacambira-Monte Azul block and correlations with other Archean blocks}

The Archean evolutionary history of the São FranciscoCongo paleocontinent is polycyclic and records events extending from the Paleo- to Neoarchean (e.g., Martin et al. 1997, Barbosa \& Sabaté 2004, Barbosa et al. 2013, Lana et al. 2013, Romano et al. 2013, Farina et al. 2015, Zincone et al. 2016). The integration of the results obtained in this work with the results of Silva et al. (2016) shows that the Archean evolution of the BIMA extends from the Paleo- to Neoarchean and comprises at least four distinct tectono-magmatic events. The first magmatic event is dated to $3.37 \mathrm{Ga}$ and was responsible for the generation of the TTGs of the Porteirinha Complex (Silva et al. 2016). The second event, dated by Silva et al. (2016) to $3.14 \mathrm{Ga}$, is characterized by the zircon metamorphic overprinting developed in the rocks of this complex. The textural aspects of these zircons indicate that this metamorphic event reached granulite-facies conditions. The third event, defined from the results of the present work, was responsible for the reworking of the Paleoarchean continental crust at approximately $2.92 \mathrm{Ga}$. In this event, the partial melting of rocks similar in composition to the Porteirinha Complex TTGs under low-pressure and relatively high-temperature conditions was responsible for the generation of the medium-potassium-group granitoids of the Pedra do Urubu Suite. The last Archean event described in the BIMA, dated to ca. 2.66 Ga by Silva et al. (2016), was responsible for the generation of the BAp high-potassium syenogranites from the fluid-present partial melting of the medium-potassium Mesoarchean granitoids.

Briefly, based on the currently available data, the Paleoarchean rocks of the BIMA are dominated by TTGtype sodic-signature rocks. The transition from sodic to predominantly potassic calc-alkaline magmatism occurred during the Mesoarchean. The potassic granitoids commonly mark the stabilization of Archean continental land masses and are related to post-collisional, extensional setting tectonic events (Whalen $e$ al. 2004, Frost et al. 2006, Smithies \& Champion 2000, Peng et al. 2013, Laurent et al. 2014, Fu et al. 2017, Zincone et al. 2016). In this sense, the Mesoarchean tectono-metamorphic event described by Silva et al. (2016) may be related to a possible collision between distinct Archean blocks (or nuclei), resulting in significant crustal thickening with subsequent lithospheric delamination followed by gravitational collapse. The presence of magmatic epidote suggests that the ascent and emplacement of this magma occurred within a short period of time (Jayananda et al. 2006). This fact, together with the relatively low-pressure conditions estimated for its source, is consistent with the interpretation of an extensional environment for the generation of these granitoids. The lithospheric delamination process would have provided the thermal inflow necessary for the partial melting of the TTGs of the Porteirinha Complex, thus allowing for the generation of the medium-potassium-group granitoids.

Because current knowledge about the Paleo- to Mesoarchean rocks in the BIMA is still limited, their correlation with the other blocks that comprise the basement of the São Francisco paleocontinent is restricted. However, some considerations can be made. In the southern portion of the São Francisco Craton (Fig. 1), within the Belo Horizonte, Santa Bárbara, Bação and Bonfin complexes, medium-K granitoids with TTG-like signatures formed by the mixing of melts produced by the partial melting of metabasalts and TTGs were generated during the Rio das Velhas I (between 2.92 and $2.85 \mathrm{Ga}$ ) and Rio das Velhas II (between 2.80 and $2.76 \mathrm{Ga}$ ) events (Lana et al. 2013, Farina et al. 2015). During the later stages of both of these events, Farina et al. (2015) described the generation of the so called kfs-bearing granitoids, which were formed exclusively by the reworking of TTG rocks. The crystallization age of 2917.5 $\pm 9.2 \mathrm{Ma}$ obtained for the PUp granodiorite is consistent with the beginning of the Rio das Velhas I event; however, its chemical signature is not related to the rocks generated during this period. In fact, the signatures of the PUp and the $\mathrm{RGp}$ resemble that of the kfs-bearing granitoids (Figs. 5, $6,8,10$ and 11). Thus, it is possible that the rocks of the medium-potassium group represent the stabilization of the previously proposed event, which would have preceded the Rio das Velhas I event.

During the course of the Neoarchean, the high-potassium group marked a new crustal stabilization event. Neoarchean potassic granitoids with ages between $2.75 \mathrm{Ga}$ and 2.6 Ga produced by crustal reworking are common in the Gavião block, which is located to the north of the BIMA, as well as in the southern São Francisco craton (Fig. 1C; Cruz et al. 2012, Santos-Pinto et al. 2012, Romano et al. 2013, Farina et al. 2015, Moreno et al. 2017). Consequently, ca. 2.6 Ga, all of the Archean continental crust exposed in the BIMA, the Gavião block and the southern core of the São Francisco craton would have constituted stable continental blocks.

However, to better understand the Archean evolution of the Itacambira-Monte Azul block, detailed lithochemical and isotopic analyses should be carried out on the other plutons of the Rio Itacambiruçu Supersuite, as well as on the various lithotypes that constitute the Porteirinha Complex. With these data, it will be possible to define their evolutions with greater reliability and thus to make more precise correlations between the other Archean blocks that comprise the substrate of the São Francisco-Congo paleocontinent. 


\section{CONCLUSIONS}

The petrographic and geochemical results obtained for the Pedra do Urubu, Rio Gorutuba and Barrocáo plutons, in addition to the $\mathrm{U}-\mathrm{Pb}$ geochronological results performed in this work and those obtained by Silva et al. (2016), yield the following conclusions:

two Archaean crustal reworking events that generated potassic granitoids can be distinguished in the BIMA;

- these granitoids can be divided into a medium-potassium group, in which the granodiorites and monzogranites of the Pedra du Urubu Suite are classified, and a high-potassium group, which is represented by the syenogranites of the Barrocão Suite. These rocks are inserted in the Rio Itacambiruçu Supersuite;

during the Mesoarchean, the partial melting of TTG-like sources under low-pressure and relatively high-temperature conditions formed the granodiorite magmas of the Pedra do Urubu pluton. The fractional crystallization of this magma, which was dominated by the fractionation of accessory phases such as titanite, allanite, epidote and zircon, formed the Rio Gorutuba magma;

during the Neoarchean, another crustal reworking event generated the precursor magma of the Barrocão pluton. The origin of this magma is probably related to the fluid-present partial melting of the medium-potassium-group granitoids;

the lower intercept ages ca. $530 \mathrm{Ma}$ indicate that the rocks of the Rio Itacambiruçu Supersuite were affected by the Brasiliano tectonometamorphic event.

\section{ACKNOWLEDGEMENTS}

We would like to thank the financial support provided by FAPEMIG (CRA-APQ-00125-12) and the Coordenação de Aperfeiçoamento de Pessoal de Nível Superior (CAPES), by granting a PhD scholarship to S.M. Bersan. We also thank the two anonymous reviewers for the thorough revision of the manuscript and for their insightful comments that substantially improved this manuscript.

\section{REFERENCES}

Alkmim F.F. 2004. O que faz de um cráton um cráton? O cráton do São Francisco e as revelações Almeidianas ao delimitá-lo. In: Mantesso Neto V., Bartorelli A., Carneiro C.D.R., Brito-Neves B.B. (Orgs.). Geologia do Continente Sul-Americano: Evolução da obra de Fernando Flávio Marques de Almeida. São Paulo, Beca, p. 17-35.

Alkmim F.F., Brito Neves B.B., Castro Alves J.A. 1993. Arcabouço tectônico do Cráton do São Francisco - Uma Revisão. In: Dominguez J.M.L. \& Misi A. (Eds.). O Cráton do São Francisco. Salvador, SBG/ Núcleo BA/SE, SGM/BA, p. 45-62.

Alkmim F.F., Marshak S., Pedrosa-Soares A.C., Peres G.G., Cruz S.C.P., Whittington A. 2006. Kinematic Evolution of the Aracuaí-West Congo orogen in Brazil and Africa: Nutcracker tectonics during the Neoproterozoic assembly of Gondwana. Precambrian Research, 149:43-64. https://doi.org/10.1016/j.precamres.2006.06.007

Alkmim F.F., Teixeira W. 2017. The Paleoproterozoic Mineiro Belt and the Quadrilátero Ferrífero. In: Heilbron M., Cordani U.G., Alkmim F.F. (Eds.). São Francisco Craton, Eastern Brazil: Tectonic Genealogy of a Miniature Continent. Switzerland, Springer International Publishing, p. 71-94.

Almeida F.F.M. 1977. O cráton do São Francisco. Revista Brasileira de Geociências, 23(7):349-364.

Almeida J.A.C., Dall'Agnol R., Dias S.B., Althoff F.J. 2010. Origin of the Archean leucogranodiorite-granite suites: evidence from the Rio Maria terrane and implications for granite magmatism in the Archean. Lithos, 120:235-257. https://doi.org/10.1016/j.lithos.2010.07.026

Almeida J.A.C., Dall'Agnol R., Leite A.A.S. 2013. Geochemistry and zircon geochronology of the Archean granite suites of the Rio Maria granite-greenstone terrane, Carajás Province, Brazil. Journal of South American Earth Sciences, 42:103-126. https://doi.org/10.1016/j. jsames.2012.10.008

Armstrong R.L. 1981. Radiogenic isotopes: the case for crustal recycling on a nearsteady-state no-continental-growth Earth. Philosophical Transactions of the Royal Society of London, 301:443472. DOI: 10.1098/rsta.1981.0122
Barbosa J.S., Sabaté P. 2004. Archean and Paleoproterozoic crust of the São Francisco cráton, Bahia, Brazil: geodynamic feactures. Precambrian Research, 133(3):1-27. DOI: 10.1016/j. precamres.2004.03.001

Barbosa J.S.F., Barbosa R.G. 2017. The Paleoproterozoic Eastern Bahia Orogenic Domain. In: Heilbron M., Cordani U.G., Alkmim F.F. (Eds.). São Francisco Craton, Eastern Brazil: Tectonic Genealogy of a Miniature Continent. Switzerland, Springer International Publishing, p. 57-69.

Barbosa N.S., Teixeira W., Leal L.R.B., Leal A.B.M. 2013. Evolução crustal do setor ocidental do Bloco Arqueano Gavião, Cráton do São Francisco, com base em evidências U-Pb, Sm-Nd e Rb-Sr. Geologia USP, 13(4):63-88.

Bea F., Fershtater G., Corretgé L.G. 1992. The geochemistry of phosphorus in granite rocks and the effect of aluminium. Lithos, 29:43-56. https://doi.org/10.1016/0024-4937(92)90033-U

Beard J.S., Lofgren G.E. 1991. Dehydration Melting and WaterSaturated Melting of Basaltic and Andesitic Greenstones and Amphibolites at 1, 3, and $6.9 \mathrm{~kb}$. Journal of Petrology, 32:365-401. DOI: 10.1093/petrology/32.2.365

Belousova E.A., Kostitsyn Y.A., Griffin W.L., Begg G.C., O’Reilly S.Y., Pearson N.J. 2010. The growth of the continental crust: constraints from zircon Hf-isotope data. Lithos, 119(3-4):457-466. https://doi. org/10.1016/j.lithos.2010.07.024

Bersan S.M. 2015. Análise estrutural do embasamento e da cobertura no extremo norte do Cinturão de Cavalgamentos da Serra do Espinhaço. Master Dissertation, Departamento de Geologia, Universidade Federal de Ouro Preto, Ouro Preto, 107 p.

Bertoldo A.L. 1993. Comportamento estrutural dos supergrupos São Francisco e Espinhaço e do embasamento entre a serra do Espinhaço setentrional e as serras de Monte Alto (BA) e Central (MG). Master Dissertation, Instituto de Geociências, Universidade Federal do Rio de Janeiro, Rio de Janeiro, 87 p. 
Boehnke P., Watson E.B., Trail D., Harrison T.M., Schmitt A.K. 2013. Zircon saturation re-revisited. Chemical Geology, 351:324-334. https://doi.org/10.1016/j.chemgeo.2013.05.028

Boynton W.V. 1984. Geochemistry of the rare earth elements: meteorite studies. In: Henderson P. (Ed.). Rare Earth Element Geochemistry. Amsterdam, Elsevier, p. 63-114.

Carvalho B.B., Sawyer E.W., Janasi V.A. 2016. Crustal reworking in a shear zone: transformation of metagranite to migmatite. Journal of Metamorphic Geology, 34:237-264. DOI: 10.1111/jmg.12180

Castro A. 2004. The source of granites: inferences from the Lewisian complex. Scottish Journal of Geology, 40:49-65. https://doi. org/10.1144/sjg40010049

Champion D.C., Sheraton J.W. 1997. Geochemistry and Nd isotope systematics of Archaean granites of the Eastern Goldfields, Yilgarn Craton, Australia: implications for crustal growth processes. Precambrian Research, 83:109-132. https://doi.org/10.1016/ S0301-9268(97)00007-7

Champion D.C., Smithies R.H. 2007. Geochemistry of Paleoarchean granites of the East Pilbara Terrane, Pilbara Craton, Western Australia: implications for early Archean crustal growth. In: Van Kranendonk M.J., Smithies R.H., Bennett V.C. (Eds.). Earth's Oldest Rocks: Developments in Precambrian Geology, vol. 15. Amsterdam, Elsevier, p. 369-410.

Chappell B.W. 1984. Source rocks of I- and S-type granites in the Lachlan Fold Belt, southeastern Australia. Philosophical Transactions of the Royal Society of London, 310:693-707. DOI: 10.1098/rsta.1984.0015

Cox K.G., Bell J.D., Pankhurst R.J. 1979. The Interpretation of Igneous Rocks. Australia, George Allen \& Unwin.

Crocco-Rodrigues F.A., Guimarães M.L.V., Abreu F.R., Belo de Oliveira O.A., Greco F.M. 1993. Evolução tectônica do Bloco ItacambiraMonte Azul entre Barrocão e Porteirinha (MG). In: Simpósio Nacional De Estudos Tectônicos, 4, Belo Horizonte. Resumos... Belo Horizonte, Sociedade Brasileira de Geologia, p. 212-216.

Cruz Pereira S.C., Figueiredo Barbosa J.S., Pinto M.S., Peucat J.J., Paquette J.L., Santos de Souza J., de Souza Martins V., Chemale Júnior F., Carneiro M.A. 2016. The Siderian-Orosirian magmatism in the Archean Gavião Paleoplate, Brazil: U-Pb geochronology, geochemistry and tectonic implications. Journal of South American Earth Sciences, 69:43-79. DOI: 10.1016/j.jsames.2016.02.007

Cruz S.C., Peucat J., Teixeira L., Carneiro M.A., Martins A.A.M., Santana J.S., Souza J.S., Barbosa J.S.F., Menezes-Leal A.B., Dantas E., Pimental M. 2012. The Caraguataí syenitic suite, a ca. $2.7 \mathrm{Ga}-$ old alkaline magmatism (petrology, geochemistry and $\mathrm{UePb}$ zircon ages). Southern Gavião block (São Francisco Craton), Brazil. Journal of South American Earth Science, 37:95-112. http://dx.doi. org/10.1016/j.jsames.2011.11.006

Dey S., Pandey U.K., Rai A.K., Chaki A. 2012. Geochemical and Nd isotope constraints on petrogenesis of granitoids from NW part of the eastern Dharwar craton: Possible implications for late Archaean crustal accretion. Journal of Asian Earth Science, 45:40-56. https:// doi.org/10.1016/j.jseaes.2011.09.013

Dhuime B., Hawkesworth C.J., Cawood P.A., Storey C.D. 2011. A change in the geodynamics of continental growth 3 billion years ago. Science, 335:1334-1336. DOI: 10.1126/science.1216066

Drumond J.B.V., von Sperling E., Raposo F.O. 1980. Projeto PorteirinhaMonte Azul. Belo Horizonte, DNPM-CPRM. 559 p.

Farina F., Albert C., Lana C. 2015. The Neoarchean transition between medium-and high-K granitoids: Clues from the Southern São Francisco Craton (Brazil). Precambrian Research, 266:375-394. https://doi.org/10.1016/j.precamres.2015.05.038
Feio G.R.L., Dall'Agnol R., Dantas E.L., Macambira M.J.B., Santos J.O.S., Althoff F.J., Soares J.E.B. 2013. Archean granitoid magmatism in the Canaã dos Carajás area: implications for crustal evolution of the Carajás Province, Amazonian craton, Brazil. Precambrian Research, 227:157-185. https://doi.org/10.1016/j.precamres.2012.04.007

Fonseca E. 1993. Depósito aurífero de Riacho dos Machados, norte de MG: Hidrotermalismo, deformação e mineralizações associadas. Master Dissertation, Instituto de Geociências, Universidade Federal de Minas Gerais, Belo Horizonte, 179 p.

Fonseca E., Lobato L.M., Baares F.J. 1996. Evolução geoquímica do Grupo Riacho dos Machados, portador de mineralização aurífera. Geochimica Brasiliensis, 10(2):417-442.

Frost B.R., Barnes C.G., Collins W.J., Arculus R.J., Ellis D.J., Frost C.D. 2001. A geochemical classification for granitic rocks. Journal of Petrology, 42:2033-2048. DOI: 10.1093/petrology/42.11.2033

Frost C.D., Frost B.R., Kirkwood R., Chamberlain K.R. 2006. The tonalite-trondhjemite-granodiorite (TTG) to granodiorite-granite (GG) transition in the late Archean plutonic rocks of the central Wyoming Province. Canadian Journal Earth Science, 43:1419-1444. https://doi.org/10.1139/e06-082

Fu J., Liu S., Wang M., Chen X., Guo B., Hu F. 2017. Late Neoarchean monzogranitic-syenogranitic gneisses in the Eastern HebeiWestern Liaoning Province, North China Craton: Petrogenesis and implications for tectonic setting. Precambrian Research, 303:392413. http://dx.doi.org/10.1016/j.precamres.2017.05.002

Gill T.B. 1981. Orogenic Andesite and Plate Tectonics. Berlin, Springer-Verlag, $390 \mathrm{p}$

Grossi-Sad J.H., Lobato L.M., Pedrosa-Soares A.C., Soares Filho B.S. 1997. Projeto Espinhaço em CD-ROM (textos, mapas e anexos). Belo Horizonte, COMIG, 2693 p

Guimarães M.L.V., Crocco-Rodrigues F.A., Abreu F.R., Belo de Oliveira O.A., Greco F.M. 1993. Geologia do Bloco Itacambira-Monte Azul entre Barrocão e Porteirinha (MG). In: Simpósio Nacional De Estudos Tectônicos, 4, Belo Horizonte. Resumos... Belo Horizonte, Sociedade Brasileira de Geologia, p. 74-78.

Guitreau M., Blichert-Toft J., Martin H., Mojzsis S., Albarède F. 2012. Hafnium isotope evidence from Archean granitic rocks for deepmantle origin of continental crust. Earth and Planetary Science Letters, 337-338:211-223. DOI: 10.1016/j.epsl.2012.05.029

Halla J., Whitehouse M.J., Ahmad T., Bagai Z. 2017. Archaean granitoids: an overview and significance from a tectonic perspective. In: Halla J., Whitehouse M.J., Ahmad T., Bagai Z. (Eds.). Crust-Mantle Interactions and Granitoid Diversification: Insights from Archaean Cratons. Geological Society, London, Special Publications, 449:1-18.

Harrison T.M., Watson E.B. 1984. The behavior of apatite during crustal anatexis: equilibrium and kinetic considerations. Geochimica et Cosmochimica Acta, 48:1467-1477. https://doi. org/10.1016/0016-7037(84)90403-4

Jackson S.E., Pearson N.J., Griffin W.L., Belousova E.A. 2004. The application of laser ablation-inductively coupled plasma-mass spectrometry to in situ U-Pb zircon geochronology. Chemical Geology, 211:47-69. https://doi.org/10.1016/j.chemgeo.2004.06.017

Janousek V., Farrow C.M., Erban V. 2006. Interpretation of wholerock geochemical data in igneous geochemistry: introducing Geochemical Data Toolkit (GCDkit). Journal of Petrology, 47(6):12551259. https://doi.org/10.1093/petrology/eg1013

Jayananda M., Chardon D., Peucat J.J., Capdevila R. 2006. 2.61 Ga potassic granites and crustal reworking in the western Dharwar craton, southern India: Tectonic, geochronologic and geochemical constraints. Precambrian Research, 150:1-26. https://doi. org/10.1016/j.precamres.2006.05.004 
Knauer L.G., Silva L.L, Souza F.B.B., Silva L.R., Carmo R.C. 2007. Folha Monte Azul, SD.23-Z-D-II, 1:100.000. Belo Horizonte, UFMG/ CPRM. 72 p.

Lana C., Alkmim F.F., Armonstrong R., Scholz R., Romano R., Nalini Jr. H.R. 2013. The ancestry and magmatic evolution of Archaean TTG rocks of the Quadrilátero Ferrífero province, Southeast Brazil. Precambrian Research, 231:157-173. https://doi.org/10.1016/j. precamres.2013.03.008

Laurent O., Martin H., Moyen J.-F., Doucelance R. 2014. The diversity and evolution of late-Archean granites: Evidence for the onset of a "modern-style" platetectonics between 3.0 and $2.5 \mathrm{Ga}$. Lithos, 205:208-235. DOI: 10.1016/j.lithos.2014.06.012

Ludwig K.R. 2003. User's Manual for Isoplot/Ex, Version 3.0, A geochronological toolkit for Microsoft Excel. Berkeley Geochronology Center Special Publication, 4, 73p.

Manya S. 2016. Petrogenesis and emplacement of the TTG and K-rich granites at the Buzwagi gold mine, northern Tanzania: Implications for the timing of gold mineralization. Lithos, 256-257:26-40. DOI: 10.1016/j.lithos.2016.03.025

Manya S., Maboko M.A.H., Nakamura E. 2007. Geochemistry and $\mathrm{Nd}$-isotopic composition of potassic magmatism in the Neoarchaean Musoma-Mara Greenstone Belt, northern Tanzania. Precambrian Research, 159:231-240. https://doi.org/10.1016/j. precamres.2007.07.001

Martin H., Peucat J.J., Sabaté P., Cunha J.C. 1997. Crustal evolution in the early Archean of South America: example of the Sete Voltas Massif, Bahia State, Brazil. Precambrian Research, 82:35-62. https:// doi.org/10.1016/S0301-9268(96)00054-X

Martin H., Moyen J.F., Rapp R.P. 2009. The sanukitoid series: magmatism at the Archaean-Proterozoic transition. Earth Environmental Science Transactions of the Royal Society of Edinburgh, 100(1-2):15-33. https://doi.org/10.1017/S1755691009016120

Martin H., Smithies R., Rapp R.P., Moyen J.F., Champion D. 2005. An overview of adakite, TTG, and sanukitoid: relationships and some implications for crustal evolution. Lithos, 79(1-2):1-24. https://doi. org/10.1016/j.lithos.2004.04.048

McDonough W.F., Sun S.S. 1995. Composition of the Earth. Chemical Geology, 120:223-253. https://doi. org/10.1016/0009-2541(94)00140-4

Mikkola P., Lauri L.S., Käpyaho A. 2012. Neoarchean leucogranitoids of the Kianta Complex, Karelian Province, Finland: Source characteristics and processes responsible for the observed heterogeneity. Precambrian Research, 206-207:72-86. https://doi. org/10.1016/j.precamres.2012.02.010

Miller C.F., McDowell S.M., Mapes R.W. 2003. Hot and cold granites? Implications of zircon saturation temperatures and preservation of inheritance. Geology, 31(6):529-532. https://doi. org/10.1130/0091-7613(2003)031\%3C0529:HACGIO\%3E2.0.CO;2

Misra S., Reinhardt J., Wilson A.H. 2017. Petrochemical evolution of the White Mfolozi granite pluton: Evidence for a late Palaeoarchaean A-type granite from the SE Kaapvaal craton, South Africa. Lithos, 286-287:480-501. https://doi.org/10.1016/j.lithos.2017.05.022

Moreno J.A., Baldim M.R., Semprich J., Oliveira E.P., Verma S.K., Teixeira W. 2017. Geochronological and geochemical evidences for extension-related Neoarchean granitoids in the southern São Francisco Craton, Brazil. Precambrian Research, 294:322-343. https://doi.org/10.1016/j.precamres.2017.04.011

Moyen J.F. 2011. The composite Archaean grey gneisses: petrological significance, and evidence for a non-unique tectonic setting for Archaean crustal growth. Lithos, 123(1-4):21-36. DOI: 10.1016/j. lithos.2010.09.015
Moyen J.F., Martin H. 2012. Forty years of TTG research. Lithos, 148:312-336. https://doi.org/10.1016/j.lithos.2012.06.010

Moyen J.F., Martin H., Jayananda M., Auvray B. 2003. Late Archaean granites: a typology based on the Dharwar Craton (India). Precambrian Research, 127:103-123. https://doi.org/10.1016/ S0301-9268(03)00183-9

Nesbitt H.W., Young G.M. 1982. Early Proterozoic climates and plate motions inferred from major element chemistry of lutites. Nature, 299:715-717. DOI: 10.1038/299715a0

Noce C.M., Pedrosa-Soares A.C., Silva L.C., Armstrong R., Piuzana D. 2007. Evolution of polycyclic basement complexes in Araçuaí Orogen, based on U-Pb SHRIMP data: Implicatons for Brazil-Africa links in Paleoproterozoic time. Precambrian Research, 159:60-78. https://doi.org/10.1016/j.precamres.2007.06.001

O'Connor J.T. 1965. A classification for quartz-rich igneous rocks based on feldspar ratios. Virginia: US Geological Survey Professional Paper B525, USGS, p. 79-84

Ohta T., Arai H. 2007. Statistical empirical index of weathering in igneous rocks: A new tool for evaluating the degree of weathering. Chemical Geology, 240:280-297. DOI: 10.1016/j. chemgeo.2007.02.017

Patiño Douce A.E. 2005. Vapor-absent melting of tonalite at 1532kbar. Journal of Petrology, 46:275-290. https://doi.org/10.1093/ petrology/egh071

Peng T.P., Wilde S.A., Fan W.M., Peng B.X. 2013. Late Neoarchean potassic high $\mathrm{Ba}-\mathrm{Sr}$ granites in the Taishan granite-greenstone terrane: Petrogenesis and implications for continental crustal evolution. Chemical Geology, 344:23-41. https://doi.org/10.1016/j. chemgeo.2013.02.012

Philpotts A.R. 1990. Principle of igneous and metamorphic petrology. New Jersey, Prentice Hall, 498 p.

Rapp R.P., Watson E.B. 1995. Dehydration melting of metabasalt at 8-32 kbar: implications for continental growth and crust-mantle recycling. Journal of Petrology, 36:891-931. https://doi.org/10.1093/ petrology/36.4.891

Ridley J.R., Vearncombe J.R., Jelsma H.A. 1997. Relations between greenstone belts and associated granitoids. In: de Wit MJ, Ashwal LD (Eds.). Greenstone belts. London, Oxford University Press, p. 376-397.

Romano R., Lana C., Alkmim F.F., Stevens G.S., Armstrong R. 2013. Stabilization of the southern portion of the São Francisco Craton, SE Brazil, through a long-livedperiod of potassic magmatism. Precambrian Research, 224:143-159. https://doi.org/10.1016/j. precamres.2012.09.002

Salvador A. 1994. Lithostratigraphic units. In: Salvador A. (Ed.). International Stratigraphic Guide: a guide to stratigraphic classification, terminology and procedure. Geological Society of America (International Subcomission on Stratigraphic Classification of International Union of Geological Sciences - IUGS; International Comission on Stratigraphy), $214 \mathrm{p}$

Santos M.M., Lana C., Scholz R., Buick I., Schmitz M.D., Kamo S.L., Gerdes A., Corfu F., Tapster S., Lancaster P., Storey C.D., Basei M.A.S., Tohver E., Alkmim A., Nalini H., Krambrock K., Fantini C., Wiedenbeck M. 2017. A New Appraisal of Sri Lankan BB Zircon as a Reference Material for LA-ICP-MS U-Pb Geochronology and Lu-Hf Isotope Tracing. Geostandards and Geoanalytical Research, 41(3):335-358. DOI: 10.1111/ggr.12167

Santos-Pinto M., Peucat J.J., Martin H., Barbosa J.S.F., Fanning C.M., Cocherie A., Paquette J.L. 2012. Crustal evolution between 2.0 and 3.5 Ga in the southern Gavião block (Umburanas-Brumado-Aracatu region), Sâo Francisco Craton, Brazil. A 3.5-3.8 Ga proto-crust in the Gavião block? Journal of South America Earth Sciences, 40:129-142. DOI: 10.1016/j.jsames.2012.09.004 
Shirey S.B., Hanson G.N. 1984. Mantle-derived Archaean monozodiorites and trachyandesites. Nature, 310:222-224. DOI: 10.1038/310222a0

Silva L.C. da, Armstrong R., Noce C.M., Carneiro M.A., Pimentel M.M., Pedrosa-Soares A.C., Leite C.A., Vieira V.S., Silva M.A., Castro V.J., Cardoso Filho J.M. 2002. Reavaliação da evolução geológica em terrenos precambrianos brasileiros, com base em novos dados U-Pb SHRIMP, Parte II: orógeno Araçuaí, Cinturão mineiro e Cráton São Francisco Meridional. Revista Brasileira de Geociências, 32(4):513-528.

Silva L.C. da, Pedrosa-Soares A.C., Armstrong R., Pinto C.P., Magalhães J.T.R., Pinheiro M.A.P., Santos G.G. 2016. Disclosing the Paleoarchean to Ediacaran history of the São Francisco craton basement: The Porteirinha domain (northern Araçuaí orogen, Brazil). Journal of South American Earth Sciences, 68:50-67. https://doi.org/10.1016/j.jsames.2015.12.002

Sisson T., Ratajeski K., Hankins W., Glazner A. 2005. Voluminous granitic magmas from common basaltic sources. Contributions to Mineralogy and Petrology, 148:635-661.

Skjerlie K.P., Johnston A.D. 1992. Vapor-absent melting at $10 \mathrm{kbar}$ of a biotite- and amphibole-bearing tonalitic gneiss: Implications for the generation of A-type granites. Geology, 20:263-266. https://doi. org/10.1130/0091-7613(1992)020\%3C0263:VAMAKO\%3E2.3.CO;2

Skjerlie K.P., Patiño-Douce A.E., Johnston A.D. 1993. Fluid absent melting of a layered crustal protolith: implications for the generation of anatectic granites. Contributions to Mineralogy and Petrology, 114:365-378.

Smithies R.H., Champion D.C. 2000. The Archaean high-Mg diorite suite: links to tonalite-trondhjemite-granodiorite magmatism and implications for early Archaean crustal growth. Journal of Petrology, 41(12):1653-1671. DOI: 10.1093/petrology/41.12.1653
Teixeira W., Oliveira E.P., Marques L.S. 2017. Nature and Evolution of the Archean Crust of the São Francisco Craton. In: Heilbron M., Cordani U.G., Alkmim F.F. (Eds.). São Francisco Craton, Eastern Brazil: Tectonic Genealogy of a Miniature Continent. Switzerland, Springer International Publishing, p. 29-56.

Van Achterbergh E., Ryan C.G., Jackson S.E., Griffin W.L. 2001. Data reduction software for LA-ICP-MS: appendix. In: Sylvester P.J. (Ed.). Laser Ablation-ICP Mass Spectrometry in the Earth Sciences: Principles and Applications, vol. 29. Ottawa, Ontario, Canada, p. 239-243.

Watkins J.M., Clemens J.D., Treloar P.J. 2007. Archaean TTGs as sources of younger granitic magmas: melting of sodic metatonalites at 0.6$1.2 \mathrm{GPa}$. Contributions to Mineralogy and Petrology, 154:91-110.

Watson E.B., Harrison T.M. 1983. Zircon saturation revisited: temperature and composition effects in a variety of crustal magma types. Earth and Planetary Science Letters, 64:295-304. https://doi. org/10.1016/0012-821X(83)90211-X

Whalen J.B., Percival J.A., McNicoll V.J., Longstaffe F.J. 2004. Geochemical and isotopic ( $\mathrm{Nd}-\mathrm{O})$ evidence bearing on the origin of late- to post-orogenic high- $\mathrm{K}$ granitoid rocks in the Western Superior Province: implications for late Archean tectonomagmatic processes. Precambrian Research, 132:303-326. DOI: 10.1016/j. precamres.2003.11.007

Zincone S.A., Oliveira E.P., Laurent O., Zhang H., Zhai M. 2016. 3.30 $\mathrm{Ga}$ high-silica intraplate volcanic-plutonic system of the Gavião Block, São Francisco Craton, Brazil: Evidence of an intracontinental rift following the creation of insulating continental crust. Lithos, 266-267:414-434. https://doi.org/10.1016/j.lithos.2016.10.011 